\title{
Economic costs of invasive alien species in Spain
}

\author{
Elena Angulo', Liliana Ballesteros-Mejia', Ana Novoa², \\ Virginia G. Duboscq-Carra ${ }^{3}$, Christophe Diagne', Franck Courchamp'
}

I Université Paris-Saclay, CNRS, AgroParisTech, Ecologie Systématique Evolution, 91405, Orsay, France 2 Department of Invasion Ecology, Institute of Botany, Czech Academy of Sciences, CZ-252 43 Prühonice, Czech Republic 3 Grupo de Ecología de Invasiones, INIBIOMA, CONICET, Universidad Nacional del Comahue, Quintral 1250, San Carlos de Bariloche, CP 8400, Argentina

Corresponding author: Elena Angulo (elenaanguloaguado@gmail.com)

Academic editor: Rafael Zenni | Received 1 October 2020 | Accepted 7 January 2021 | Published 29 July 2021

Citation: Angulo E, Ballesteros-Mejia L, Novoa A, Duboscq-Carra VG, Diagne C, Courchamp F (2021) Economic costs of invasive alien species in Spain. In: Zenni RD, McDermott S, García-Berthou E, Essl F (Eds) The economic costs of biological invasions around the world. NeoBiota 67: 267-297. https://doi.org/10.3897/neobiota.67.59181

\begin{abstract}
Economic assessments for invasive alien species (IAS) are an urgent requirement for informed decisionmaking, coordinating and motivating the allocation of economic and human resources for the management of IAS. We searched for economic costs of IAS occurring in Spain, by using the InvaCost database and requesting data to regional governments and national authorities, which resulted in over 3,000 cost entries. Considering only robust data (i.e. excluding extrapolated, potential (not-incurred or expected) and low reliability costs), economic costs in Spain were estimated at US\$ 261 million (€ 232 million) from 1997 to 2022 . There was an increase from US\$ 4 million per year before 2000 to US\$ 15 million per year in the last years (from $€ 4$ to 13 million). Robust data showed that most reported costs of IAS in Spain (>90\%) corresponded to management costs, while damage costs were only found for 2 out of the 174 species with reported costs. Economic costs relied mostly on regional and inter-regional administrations that spent $66 \%$ of costs in post-invasion management actions, contrary to all international guidelines, which recommend investing more in prevention. Regional administrations unequally reported costs. Moreover, $36 \%$ of the invasive species, reported to incur management costs, were not included in national or European regulations (i.e. Black Lists), suggesting the need to review these policies; besides, neighbouring regions seem to manage different groups of species. We suggest the need of a national lead agency to effectively coordinate actions, facilitate communication and collaboration amongst regional governments, national agencies and neighbouring countries. This will motivate the continuity of long-lasting management actions and the increase in efforts to report IAS costs by regional and inter-regional managers which will adequately provide information for future budgets gaining management effectiveness.
\end{abstract}

Copyright Elena Angulo et al. This is an open access article distributed under the terms of the Creative Commons Attribution License (CC BY 4.0), which permits unrestricted use, distribution, and reproduction in any medium, provided the original author and source are credited. 


\section{Abstract in Spanish}

Costos económicos de las especies exóticas invasoras en España. Las evaluaciones de los costos de las especies exóticas invasoras (EEI) son un requisito urgente para informar en la toma de decisiones, coordinar y motivar la asignación de recursos económicos y humanos para la gestión de las EEI. En este estudio, buscamos información sobre los costos económicos de las EEI en España, usando la base de datos InvaCost, y solicitando datos a las administraciones regionales y nacionales, lo que resultó en más de 3000 entradas de costos. Considerando solamente los costos robustos (es decir, excluyendo los costos extrapolados, potenciales (no observados o esperados) o de baja fiabilidad), los costos económicos de EEI en España fueron estimados en 261 millones de dólares americanos (US\$, 232 millones de €) entre 1997 y 2022. Observamos un incremento desde 4 millones de US\$ por año antes del año 2000 hasta 15 millones de US\$ por año en los últimos años (de 4 a 13 millones de $€$ ). Los datos robustos indicaron que la mayoría de los costos reportados en España (>90\%) correspondieron a costos de gestión, mientras que los daños económicos sólo fueron observados para 2 de las 174 especies con costos reportados. Los costos económicos correspondieron principalmente a las administraciones regionales o inter-regionales que gastaron $66 \%$ de los costos en acciones de manejo después de la invasión, al contrario de lo recomendado en las guías internacionales, que es invertir más en prevención. Las administraciones regionales reportaron de manera desigual los costos. En este sentido, el $36 \%$ de las especies invasoras reportadas con costos de gestión no estaban incluidas en las leyes nacionales o Europeas (listas negras), lo que sugiere la necesidad de revisar esas leyes; además, las regiones vecinas parecen gestionar diferentes grupos de especies. Sugerimos la necesidad de una agencia que coordine las acciones de manera efectiva a nivel nacional, y facilite la comunicación y la colaboración entre gobiernos regionales, agencias nacionales y países vecinos. Esto motivará la continuidad de las acciones de gestión a largo plazo, que proveerán de información adecuada a los futuros presupuestos, ganando en efectividad en la gestión.

\section{Abstract in French}

Coûts économiques des espèces exotiques envahissantes en Espagne. Les évaluations économiques des espèces exotiques envahissantes (EEE) sont une nécessité urgente pour motiver et orienter les actions des autorités et décideurs en matière de gestion des EEE. Nous avons recherché les coûts économiques des EEE en Espagne via (i) la base de données InvaCost et (ii) des sollicitations adressées aux gouvernements régionaux et autorités nationales. Ce travail a abouti à l'obtention de plus de 3000 données individuelles de coûts. Si l'on ne tient compte que des données considérées comme les plus robustes (c'est-à-dire lorsqu'on exclut les coûts extrapolés, potentiels (i.e. prédits ou non-observés) et/ou peu fiables d'un point de vue méthodologique), les coûts économiques en Espagne ont été estimés à 261 millions de dollars américain (232 millions d'euros) entre 1997 et 2022. Il y a eu une augmentation annuelle de 4 millions de dollars avant 2000, puis de 15 millions de dollars par an ces dernières années. Ces données robustes ont montré que la plupart des coûts déclarés des EEE en Espagne (> 90\%) correspondaient aux coûts de gestion, tandis que les coûts des dommages n'ont été constatés que pour 2 des 174 espèces dont les coûts étaient reportés. Nous avons montré que les coûts économiques reposaient principalement sur les administrations régionales et interrégionales; celles-ci ont consacré $66 \%$ des coûts enregistrés aux actions de gestion post-invasion, contrairement aux directives internationales qui recommandent d'investir davantage dans la prévention. Les administrations régionales ont déclaré les coûts de manière inégale. De plus, 36\% des espèces envahissantes, déclarées comme entraînant des coûts de gestion, n’étaient pas incluses dans les réglementations nationales ou européennes (c’est-à-dire les listes noires). Ceci suggère la nécessité de revoir ces politiques; en outre, les régions voisines semblent gérer différents groupes d'espèces. Nous suggérons la nécessité d'une agence nationale 'chef de file' pour coordonner efficacement les actions, faciliter la communication et la collaboration entre les gouvernements régionaux, les agences nationales et les pays voisins. Cela motivera la continuité des actions de gestion à long terme et l'intensification des efforts pour rendre compte des coûts des EEE par les gestionnaires régionaux et interrégionaux. Tout ceci permettra de fournir des informations adéquates pour les budgets futurs, avec un bénéfice certain pour l'efficacité des mesures de gestion. 


\section{Abstract in Italian}

Costi economici delle specie aliene invasive in Spagna. Le valutazioni economiche delle specie aliene invasive (SAI) sono un requisito urgente per processi decisionali informati, e per coordinare e motivare l'allocazione di risorse economiche e umane per la gestione delle SAI. Usando la banca dati InvaCost e richiedendo i dati ai governi regionali e alle autorità nazionali, abbiamo cercato i costi economici delle SAI presenti in Spagna, ottenendo come risultato 3000 voci di costi. Considerando solo i dati robusti (i.e. escludendo i costi estrapolati, potenziali (non sostenuti od attesi) e con bassa attendibilità), i costi economici in Spagna dal 1997 al 2022 stati stimati a 261 milioni di \$ americani (232 milioni di €). C’è stato un aumento da 4 milioni di \$ americani all'anno prima del 2000 a 15 milioni di \$ americani all'anno negli ultimi anni (da 4 a 13 milioni di $€$ ). I dati robusti hanno mostrato che la maggior parte (> 90\%) dei costi riportati per le SAI in Spagna corrispondeva a costi di gestione, mentre i costi riferiti ai danni sono stati trovati solo per 2 delle 174 specie con costi riportati. I costi economici si basano soprattutto sulle amministrazioni regionali e interregionali, che hanno speso il $66 \%$ dei costi in azioni di gestione post invasione, contrariamente a tutte le linee guida internazionali, che raccomandano di investire di più nella prevenzione. Le amministrazioni regionali hanno riportato $\mathrm{i}$ costi in modo diseguale. Inoltre, il 36\% delle specie invasive per cui sono riportati costi di gestione non era incluso nei regolamenti nazionali o europei (i.e. Liste Nere), il che suggerisce il bisogno di rivedere queste politiche; inoltre, regioni limitrofe sembrano gestire gruppi diversi di specie. Suggeriamo la necessità di un'agenzia principale nazionale per coordinare efficacemente le azioni, facilitare la comunicazione e la collaborazione tra i governi regionali, le agenzie nazionali e i Paesi vicini. Questo motiverà la continuità di azioni di gestione a lungo termine e l'aumento degli sforzi per riportare i costi delle SAI da parte dei gestori regionali e interregionali, che forniranno informazioni adeguatamente per far sì che i futuri bilanci acquisiscano efficacia gestionale.

\section{Abstract in Portuguese}

Custos econômicos das espécies invasoras na Espanha. Avaliaçôes econômicas para espécies exóticas invasoras (EEI) são uma necessidade urgente para informar, coordenar e motivar tomadores de decisão na alocação de recursos econômicos e humanos para a gestão das EEI. Nós buscamos por custos econômicos de EEI na Espanha utilizando o banco de dados InvaCost e solicitamos dados para governos regionais e autoridades nacionais, o que resultou em mais de 3.000 registros de entrada. Considerando apenas dados robustos (ou seja, excluindo custos extrapolados, potenciais (não observados ou esperados) e custos de baixa confiabilidade), os custos econômicos na Espanha foram estimados em 261 milhóes de dólares (232 milhōes de euros) de 1997 até 2022. Houve um aumento de 4 milhóes de dólares por ano, antes do ano 2000, para 15 milhóes anuais nos anos mais recentes (de 4 para 13 milhóes de euros). Com base nos dados robustos, os custos com manejo foram os mais reportados na Espanha (>90\%), enquanto custos com danos foram encontrados apenas para 2 das 171 espécies com custos reportados. Os custos econômicos dependem principalmente de administraçóes regionais e inter-regionais que gastaram $66 \%$ do recurso com açóes de manejo pós-invasão, ao contrário de todas as diretrizes internacionais que recomendam investir mais em prevenção. Administraçôes regionais reportaram os custos de forma desigual. Além disso, 36\% das espécies invasoras, que foram responsáveis por custos com manejo, não foram incluídas em regulamentaçôes nacionais ou europeias (tal como, listas de espécies indesejadas), sugerindo a necessidade de revisão dessas políticas. Ainda, regiôes vizinhas parecem gerir diferentes grupos de espécies. Nós sugerimos a necessidade de uma agência nacional central para coordenar açôes de forma efetiva, facilitar a comunicação e a colaboração entre os governos regionais, agências nacionais e países vizinhos. Isso irá motivar a continuidade de açôes de gestáo a longo prazo e o aumento dos esforços para reportar custos com EEI por gestores regionais e inter-regionais, que fornecerão informaçóes adequadas para orçamentos futuros ganhando eficácia na gestão. 


\begin{abstract}
Arabic

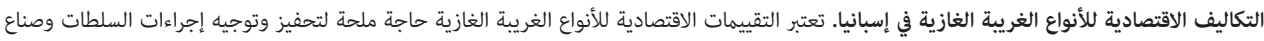

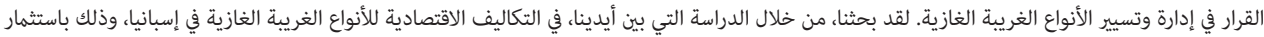

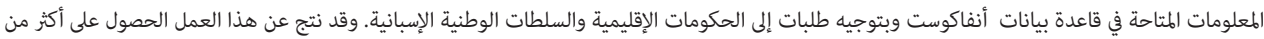

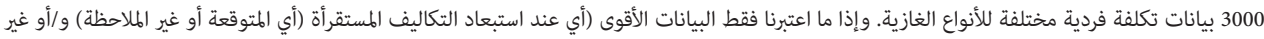

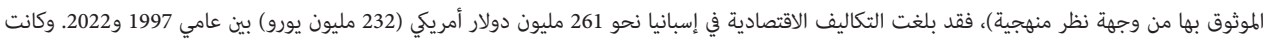

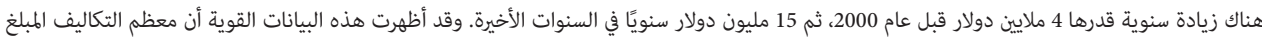

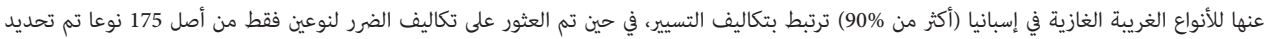

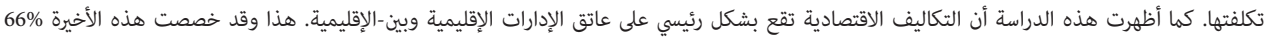

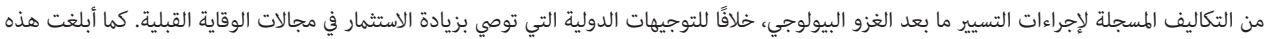

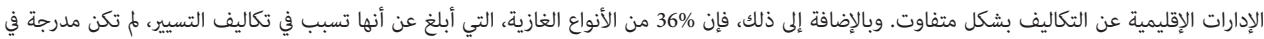

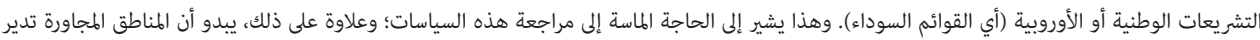

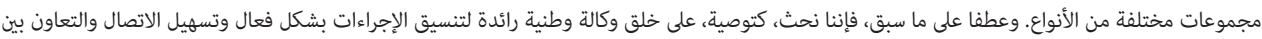

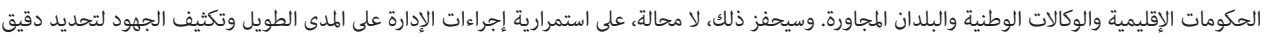
لتكاليف الأنواع الغريبة الغازية من قبل المسييرين الإقليميين وبين-الإقاليميين
\end{abstract}

\title{
Abstract in Galician
}

Custos económicos das especies exóticas invasoras en Espańa. As avaliacións económicas para especies exóticas invasoras (EEI) son un requisito urxente para a toma de decisións informadas e a coordinación e motivación da asignación de recursos económicos e humanos para a súa xestión. Neste estudo buscamos información dos custos económicos das EEI en España mediante a utilización da base de datos InvaCost e solicitude de datos aos gobernos rexionais e autoridades nacionais, o que deu lugar a máis de 3.000 entradas de custos. Considerando só datos sólidos (é dicir, excluíndo os custos extrapolables, potenciais (non ocasionados ou esperados) e de baixa fiabilidade), os custos económicos en España estimáronse en US\$ 261 millóns (232 millóns de euros) entre 1997 e 2022 . Houbo un aumento de US\$ 4 millóns ao ano antes do 2000 a US\$ 15 millóns ao ano nos últimos anos (de 4 a 13 millóns de euros). Os datos sólidos mostraron que a maioría dos custos reportados das EEI en España (> 90\%) corresponden a custos de xestión, mentres que os custos dos danos só se atoparon en 2 das 174 especies con custos notificados. Os custos económicos dependen principalmente das administracións rexionais e interrexionais que gastaron o 66\% dos custos en accións de xestión posterior á invasión, en contra de todas as directrices internacionais, que recomendan investir máis en prevención. As administracións rexionais informaron desigualmente dos custos. Ademais, o 36\% das especies invasoras con custos de xestión reportados, non foron incluídas na normativa nacional ou europea (é dicir, as listas negras), o que suxire a necesidade de revisar estas políticas; ademais, as rexións veciñas parecen xestionar diferentes grupos de especies. Suxerimos a necesidade dunha axencia líder nacional para coordinar de xeito eficaz as accións de xestión, e facilitar a comunicación e a colaboración entre gobernos rexionais, axencias nacionais e países veciños. Isto motivará a continuidade das accións de xestión de longa duración e o aumento dos esforzos para reportar os custos das EEI por parte dos xestores rexionais e interrexionais, o cal proporcionará información para os futuros orzamentos que mellorarán a eficacia da xestión de EEI.

\section{Abstract in Catalan}

Custos Costos econòmics de les espècies exòtiques invasores a Espanya. L'avaluació econòmica del impacte d'espècies exòtiques invasores (EEI) és un requisit urgent per a la presa de decisions informades, promovent i coordinant l'assignació de recursos humans i econòmics per a una gestió adequada de les EEI. Hem cercat informació sobre els costos econòmics de les EEI a Espanya, mitjançant la base de dades InvaCost i consultes als governs regionals i les autoritats nacionals, amb un resultat de més de 
3.000 entrades sobre costos. Tenint en compte només dades sòlides (és a dir, excloent els costos extrapolats, potencials (no incorreguts o esperats) i costos de baixa fiabilitat), els costos econòmics a Espanya es van estimar en 261 milions de dòlars (US\$, 232 milions d'euros) des del 1997 fins al 2022. Hi va haver un augment de 4 milions de dòlars per any abans del 2000 a 15 milions de dòlars en als darrers anys (de 4 a 13 milions d'euros). Les dades sòlides van mostrar que la majoria dels costos reportats de les EEI a Espanya (> 90\%) corresponien als costos de gestió, mentre que els costos de danys només es van trobar en 2 de les 174 espècies amb els costos reportats. Els costos econòmics es basaven principalment en administracions regionals i interregionals que gastaven el $66 \%$ dels recursos en accions de gestió postinvasió, contràriament a totes les directrius internacionals, que recomanen invertir més en prevenció. Les administracions regionals van informar desigualment de costos. D’altra banda, el 36\% de les espècies invasores, que suposaven un cost de gestió, no estaven incloses en les regulacions nacionals o europees (és a dir, les llistes negres), cosa que suggereix la necessitat de revisar aquestes polítiques; a més, les regions veïnes semblen gestionar diferents grups d'espècies. Suggerim la necessitat d'una agència líder nacional per coordinar eficaçment les accions, facilitar la comunicació i la col-laboració entre governs regionals, agències nacionals i països veïns. Això motivarà la continuïtat de les accions de gestió de llarga durada i una millora de la informació sobre els costos derivats de les EEI per part dels gestors regionals i interregionals, proporcionant la informació adequada per tal de maximitzar una eficaç gestió en futurs pressupostos.

\section{Abstract in Basque}

Espezie exotiko inbaditzaileen kostu ekonomikoak Espainian. Espezie exotiko inbaditzaileen (EEI) kudeaketarako kostuen ebaluazioa ezinbestekoa da, bai erabakiak hartzeko, informazioa emateko zein baliabide ekonomikoen eta giza baliabideen esleipena koordinatu eta motibatzeko. Ikerketa honetarako Espainiako EEIen kostu ekonomikoei buruzko informazioa bilatu genuen. Horretarako InvaCost datubasea erabiliz gain, eskualdeko eta nazioko administrazioei datuak eskatu genizkien. Guztira, bilaketak 3.000 kostu-sarrera baino gehiago ekarri zituen. Kostu sendoak bakarrik kontuan hartuta (hau da, espero ziren kostuak, aurreikusiak edo potentzialak alde batera utzita), 1997 eta 2022 bitartean Espainian EEIren kostu ekonomikoak 261 milioi dolar (232 milioi €) izan zirela kalkulatu zen. 2000. urtea baino lehen urteko kostua 4 milioi US\$-koa bazen, azken urteetan 15 milioira igo da (hau da, 4 milioi eurotik 13 milioi eurora). Datu sendoen arabera, Espainian jakinarazitako kostu gehienak ( $>90 \%)$ kudeaketakostuei zegozkien. Kalte ekonomikoak, berriz, 174 espezieetatik 2rekin bakarrik erlazionatu ziren. Kostu ekonomikoak eskualdeko edo eskualde arteko administrazioenak izan ziren batez ere. Nazioarteko gidetan gomendatzen den moduan prebentzioan gehiago inbertitu beharrean, kostuen \%66 inbasioaren ondorengo erabilera-ekintzetan gastatu zuten. Eskualdeetako administrazioek ez zituzten kostuak modu berean aurkeztu. Kudeaketarako kostuak ezarritako espezie inbaditzaileen artean, \%36a ez zen lege nazionaletan edo Europako legeetan agertzen (zerrenda beltzak). Gertaera honek, legeak berrikusteko beharra adierazten du. Horrez gain, aldameneko eskualdeek espezie-talde desberdinak kudeatzen dituztela dirudi. Hori dela eta, estatu mailan ekintzak eraginkortasunez koordinatuko dituen agentzia baten beharra iradokitzen dugu. Agentziak gainera eskualdeetako gobernuen, agentzia nazionalen eta auzoko herrialdeen arteko komunikazioa eta lankidetza erraztu beharko luke. Kudeaketa eraginkorragoa izan dadin, agentziaren sorrerak epe luzeko kudeaketa-ekintzak aurrera jarraituko dutela eta etorkizuneko aurrekontuei buruzko informazio egokia emango dela ziurtatuko luke.

\section{Keywords}

Iberian Peninsula, InvaCost, management costs, monetary impacts, non-native species, prevention costs, socioecology, stakeholders 


\section{Introduction}

Invasive alien species (IAS) can cause significant negative environmental and socioeconomic impacts (Blackburn et al. 2019). These include loss of biodiversity (Simberloff et al. 2013; Bellard et al. 2016), changes to ecosystem functioning (Ehrenfeld 2011), impacts on human health and well-being (Jeschke et al. 2014) and large economic losses. Knowledge about the economic impact of IAS is, however, generally limited geographically, taxonomically or to some socioeconomic sectors. In the 2000s, Pimentel et al. (2005) provided the first estimations of the economic costs of IAS at large spatial scales. Since then, other studies have attempted to collect further data on these costs, such as in Europe (Kettunen et al. 2009), in invasion research and management (Scalera 2010) or for specific taxonomic groups (e.g. insects, Bradshaw et al. 2016). However, available data are scarce, scattered and not easily accessible and extrapolation-based approaches underlying most of these estimates are methodologically questionable (Cuthbert et al. 2020). These fragmented data and methodological flaws are reflected by critical knowledge gaps on the economic costs of IAS for most taxa, countries and regions of the world (Aukema et al. 2011). Such economic assessments are, therefore, an urgent requirement for informed decision-making by policy-makers and other stakeholders, for coordinating and motivating the allocation of economic and human resources for the management of IAS and for raising public awareness (Hulme 2006; Andreu et al. 2009; Diagne et al. 2020a, 2021a).

Europe represents a hub for alien species introductions (Turbelin et al. 2017), of which several thousands are already established (Dawson et al. 2017), inducing substantial economic impacts to the continent (Haubrock et al. 2021a). As a consequence, there is an increasing awareness to tackle IAS throughout the continent (García-de-Lomas and Vilà 2015; Turbelin et al. 2017). With an area of $505,992 \mathrm{~km}^{2}$, Spain is one of the largest countries in Europe, presenting a considerable geographical, topographical, climatic, geological and species diversity. It also has a large diversity of IAS: the Spanish Government estimates that up to 190 alien species have already established invasive populations in the country (Spanish Catalogue of Invasive Alien Species, Royal Decree 630/2013). Spain has adopted legislation aiming at tackling biological invasions for the last 25 years. However, although the introduction of IAS was already considered as a criminal offence since 1995 (through an Organic Law, 10/1995) and the Spanish Strategy for the Conservation and Sustainable Use of Biodiversity (following the Convention of the Biological Diversity's recommendations to protect biodiversity from IAS) was developed in 1998, it was not until 2007 when policies for preventing and managing IAS were strengthened. The Law of Natural and Biodiversity Heritage (Law 42/2007) includes not only the need for prevention (through the Spanish Catalogue of Invasive Alien Species, Royal Decree 630/2013), but also the creation of strategic management plans for those IAS that threaten native species, natural habitats, agronomy and economic resources associated with environmental resources. The responsibility for implementing the Law falls into the "competent authorities", which are mainly the regional governments (i.e. the autonomous communities) and the national authorities (e.g. national authorities managing borders, continental waters or national parks that spatially correspond to more than one region). 
Andreu et al. (2009) showed that environmental managers from regional authorities in Spain were generally aware of the risks posed by biological invasions. However, they claimed that there were limited economic funds to manage invasive alien species, and a lack of coordination amongst different regional and national administrations, scientific research on the performance of different strategies to manage invasive alien species and knowledge on the economic costs of IAS in the country (Andreu et al. 2009). The latter is known to be essential to help regional and national authorities to set up efficient budgets for IAS management. In this context, the InvaCost database (Diagne et al. 2020b), the most up-to-date repository of invasion costs worldwide, provides an excellent opportunity to tackle the current lack of data on the economic costs of IAS in Spain. Here, we extracted the data available in the InvaCost database regarding the economic costs of IAS in Spain. We expanded these data by requesting further information directly from Spanish regional and national environmental managers. Our aims were to (i) describe the distribution of reported economic costs of IAS across regions, environments, taxonomic groups, cost types and economic sectors; (ii) identify those IAS causing the highest costs; and (iii) examine the temporal trends of the economic costs reported over the last decades.

\section{Methods}

\section{Data collection}

We extracted data on the costs of IAS from the most updated version of the InvaCost database: InvaCost_v.3.0 (9,823 entries, Diagne et al. 2020b, https://doi.org/10.6084/ m9.figshare.12668570) (Fig. 1a). This database consists of cost data extracted from documents obtained through standardised literature searches (i.e. using SI Web of Science platform, Google Scholar and the Google search engine) and opportunistic targeted searches (i.e. expert consultations for which data gaps were identified). One of these targeted searches addressed cost data in non-English languages (Angulo et al. 2020, https://doi.org/10.6084/m9.figshare.12928136). Cost values (including Spanish) recorded in InvaCost_v.3.0 were converted from local currencies to US $\$$ by dividing the cost estimate by the official market exchange rate corresponding to the year of the cost estimation and then to 2017 US\$ using inflation factors (Diagne et al. 2020b). From InvaCost_v.3.0, we extracted specific relevant data, resulting in a total of 3,260 entries of economic costs of IAS in Spain (Suppl. material 1; Fig. 1b).

Due to the importance of the non-English targeted search for the Spanish dataset (i.e. only 49 of the 3,260 entries in our dataset were extracted from documents written in English - 20 vs. 61 documents), we expand here the methods used by Angulo et al. (2021) to collect cost data in non-English languages. Spain is administratively divided into 17 autonomous regions (herein "regions"). Each of these regions manages IAS independently. We explored the web pages of regional government offices in charge of managing invasive species in each region and, when available, emailed environmental managers or sent administrative forms requesting economic data on the costs of IAS. 


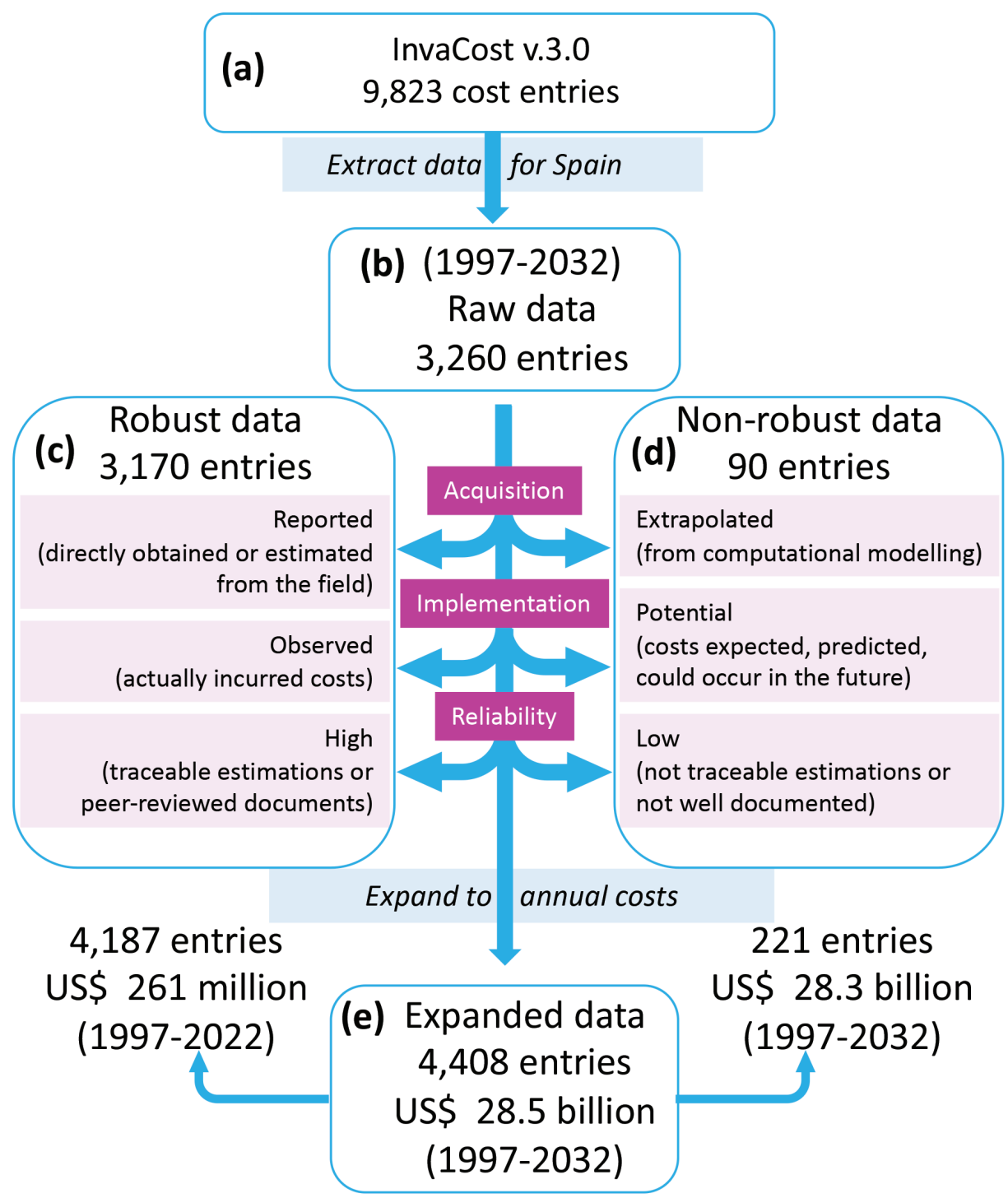

Figure I. Data collection and filtering processes (a) data sources (b) raw data (timeframe and number of entries) obtained after extracting the data for Spain; raw data were segregated in two groups (c) robust data and (d) non-robust data using three variables, acquisition, implementation and reliability (e) expanded data to obtain comparable yearly costs.

Moreover, Spanish continental waters are managed in coordination with the Ministry for the Ecologic Transition and Demographic Challenge, through independent river basin authorities (hydrographic confederations). Therefore, we searched for available information in their web pages and contacted those river basin authorities from whom we could obtain the contact details of their environmental managers (i.e. Guadiana, Tajo, Segura, Basque Country, Cantábrico). In the region of Valencia, costs were reported as working days and we transformed them into economic costs by multiplying the re- 
ported number of working days by $€ 128$ (i.e. cost per day, Vicente del Toro, Biodiversity Service, Generalitat Valenciana, pers. comm.). We obtained data for Spain up to December 2020, with costs being reported in Spanish and in two co-official languages: Catalan and Galician (Suppl. material 1: Tab InvaCost_3.0_Spain, column "language").

\section{Data structure}

Cost data extracted for Spain (herein raw data, Fig. 1b, Suppl. material 1: Tab InfoVariables) were described with a set of variables pertaining to: (i) information on the document reporting the cost, (ii) spatial information (e.g. location, spatial scale, environment - aquatic or terrestrial - and whether the location corresponds to a protected area or to an island), (iii) taxonomy of the invasive species incurring the cost, (iv) temporal information, (v) typology of costs reported (e.g. management actions or economic damages, impacted sector) and (vi) a set of variables reporting the raw cost estimates, currency used and the converted US\$ values.

With respect to the type of cost, we first used the column "type_of_cost_merged" which included three categories: "damage" costs: economic losses due to direct and/ or indirect impacts of invaders, such as yield loss, health injury, land alteration, infrastructure damage or income reduction; "management" costs: economic resources allocated to prevention, control, research, long-term management, or eradication; "mixed" costs: when costs include both damage and management expenditure. We also used the column "management_type" to divide further management costs in the following categories: "pre-invasion management": monetary investments for preventing successful invasions in an area (including quarantine or border inspection, risk analyses, biosecurity management, etc.); "post-invasion management": money spent for managing IAS in invaded areas (including control, eradication, containment); "knowledge/funding": money allocated to all actions and operations that could be of interest at all steps of management at pre- and post-invasion stages (including administration, communication, education, research etc.); "unspecified" for costs without detailed types; and a "mixed" category was assigned when costs included at least two of the above categories.

Categories for the economic sector included: "agriculture": considered at its broadest sense, such as crop growing, livestock breeding, beekeeping, land management; "authorities-stakeholders": governmental services and/or official organisations - such as conservation agencies and forest services - that allocate efforts for the management of biological invasions (e.g. control programmes, eradication campaigns, research funding); "environment": impacts on natural resources, ecological processes and/or ecosystem services; "forestry": forest-based activities and services, such as timber production/industries and private forests; "health": for every item directly or indirectly related to human health, such as control of disease vectors (e.g. mosquitoes transmitting pathogens to humans) or medical care and damage to work productivity due to impacts on health; "public and social welfare": activities, goods or services contributing to human well-being and safety in our societies, including local infrastructure, such as the electricity system, quality of life (e.g. income, recreational activities), personal goods (e.g. private properties, lands), public services (e.g. transport, water regulation) and market activities (e.g. tourism, trade). 


\section{Data processing}

Three variables about the typology of the costs are important for the further selection of the data we used (Diagne et al. 2020b): (i) the acquisition method for the cost value ("reported" if the cost data were directly obtained or derived using inference methods from fieldbased information or "extrapolated" if the cost data were obtained using computational modelling), (ii) the implementation of the cost ("observed" if the cost was actually incurred or "potential" if the cost is predicted to occur over time) and (iii) the reliability of the cost value reported ("high" or "low", based on whether the approach used for cost estimation in the document was reported and traceable). We filtered our dataset to differentiate the most robust data, i.e. directly reported, observed and highly reliable costs (corresponding to 3,170 raw entries, Fig. 1c). Indeed, we considered as non-robust data 90 cost entries that were extrapolated, not yet actually incurred and/or of low reliability (Fig. 1d).

We considered the full dataset (raw data, 3,260 entries, Fig. 1b) to explore general differences in the number of cost entries for Spain amongst descriptors. The number of entries is a good indicator of how detailed reported costs are (e.g. costs obtained from a single report for one region covering all invasive species, invaded locations, years and types of management can be assumed to be less detailed than costs obtained from several reports, each of them covering different invasive species and their management). Moreover, since the period of estimation across reported costs varied from months to years, we homogenised the cost values for the full dataset (including both robust and non-robust data) as follows: we recalculated costs covering several years on an annual basis and repeated these annual values over the duration time (in number of years) of each cost occurrence. For example, a cost reporting US\$ 500 occurring in the period 1996-2000 was transformed into five identical costs of US\$ 100 for each of those years. Costs occurring in less than one year were assumed as having occurred during a single complete year in order to avoid overestimation. Hence, we obtained comparable annual costs for all cost entries. This was performed using the "expandYearlyCosts" function of the 'invacost' package version 0.3-4 (Leroy et al. 2020 in R version 3.6.3 (R Core Team 2020). The expanded full dataset resulted in 4,408 entries (Fig. 1e) from which 4,187 cost entries correspond to robust data and 221 to non-robust data. All the analyses presented in the main text were carried out with the robust data. Results including the non-robust data are briefly presented in the first sentences of the results and shown in Figure 1 and in Suppl. material 2: Fig. S1.

\section{Data analysis}

We first described the number of entries and the economic costs for each of the 17 autonomous regions and mapped the information across the country using the package "ggplot" in R version 4.0.2 (R Core Team 2020). We also described the costs across specific descriptors: main taxonomic groups, main environments in which the costs occurred, economic sectors impacted by the cost, the spatial scale at which the costs occurred and whether or not the costs occurred in protected areas. 
We calculated the temporal trends of IAS economic impacts in Spain by using the function summarizeCosts of the "invacost package" version 0.3-4 (Leroy et al. 2020) in $\mathrm{R}$ version 3.6.3 ( $\mathrm{R}$ Core Team 2020). This function allowed us to calculate average annual costs between 1997 and 2019, providing averages in 4-year periods throughout the study period using the extended entries calculated by the "expandYearlyCosts" function described above.

Finally, we identified the costliest IAS in Spain and assessed whether the species causing economic costs in Spain are those recorded as invasive in the country or included in European or national regulations. We collected information on the identity of those alien species (i) recorded as invasive in Spain (sensu the Global Invasive Species Database; http://www.issg.org/database); (ii) included in the Spanish Catalogue of Invasive Alien Species (Royal Decree 630/2013), (iii) included in the List of Invasive Species of Union Concern (EU, No 1143/2014 of the European Parliament); and (iv) proposed as potential candidates to be included in the List of Invasive Species of Union Concern (Carboneras et al. 2018). Besides European and National regulations, some Spanish regions also present regional invasive alien species regulations. For example, in the region of Aragon, it is not allowed to introduce, catch, keep, transport or sell any freshwater alien crayfish species (Decreto 127/2006 of the Aragon Government). However, most regions rely exclusively on national and European regulations and have no specific lists of invasive alien species (with the exception of Valencia; Decreto 14/2013 of the Consell). Therefore, we only considered national and European regulations in our analysis.

\section{Results}

Costs of invasive species in Spain amounted to US\$28.52 billion ( $€ 25.38$ billion, using the 0.89 conversion factor for 2017) from 1997 to 2032 (Fig. 1e). However, although only 90 out of 3,260 raw entries were extrapolated, potential and/or unreliable costs, these constituted $99.08 \%$ of the economic costs in our dataset (Fig. 1e). Most of these high costs were driven by one single entry: a cost derived from an extrapolation of the potential loss of forestry stock caused by Bursaphelenchus mucronatus, the pine wood nematode, over a period of 22 years (2008-2030, Suppl. material 2: Fig. S1). Without considering non-robust data, the reported, observed and reliable costs for invasive species in Spain constituted US\$261.28 million (€ 232.54 million). These costs occurred from 1997 to 2020, except for two raw entries that went over this year: one corresponding to a LIFE+ project ranging from 2019 to 2022 aimed at controlling Lampropeltis californiae in the Canary Islands and the second corresponding to an annual management programme for invasive plants in Sierra Espuña Regional Park (Murcia) that included part of the year 2021. Thus, both reported budgets are considered already delivered costs.

Only using the robust dataset, we showed that the highest amount of costs was reported for plants (66\%; especially from the orders Myrtales and Commelinales), followed by arthropods (12\%; mainly insects) and mollusca (11\%; mostly bivalves) (Fig. 2a-e). Most costs corresponded to IAS from terrestrial environments (53\%), while 
(a)

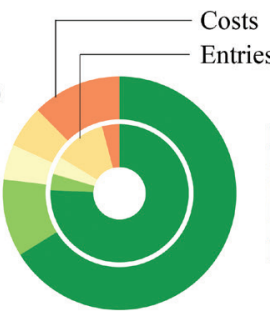

Taxonomy

(b)

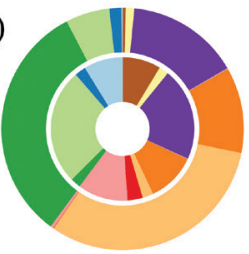

Plant taxonomy

(c)

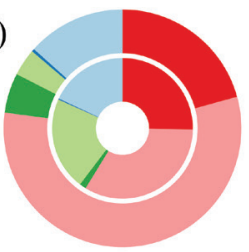

Vertebrate taxonomy

(d)

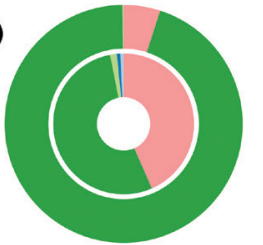

Arthropod taxonomy

(e)

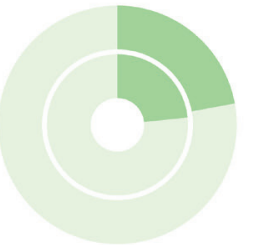

Mollusc taxonomy (f)

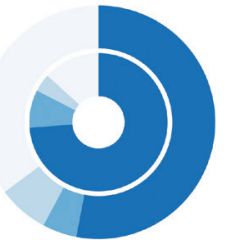

Environment

(g)

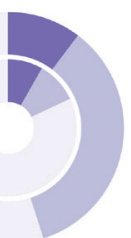

Protected area

Non protected area NA

Protection

(h)

\begin{tabular}{l} 
Actinopterygii \\
Amphibia \\
Aves \\
\hline Diverse/Unspecified \\
Mammalia \\
Reptilia
\end{tabular}

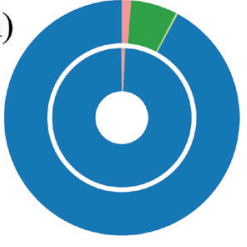

Agriculture

Authorities-Stakeholders

Environment

Mixed

Public and social welfare

Economic sector

(i)

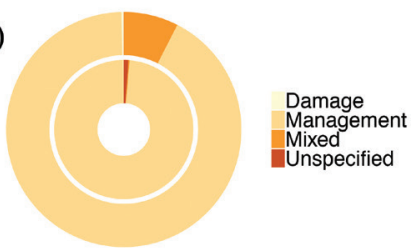

Type of cost

(j)

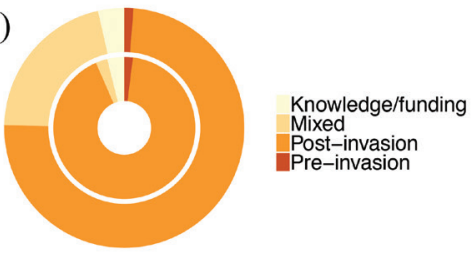

Type of management cost

Figure 2. Total economic costs (outer circles) and number of entries (inner circles) for invasive species in Spain for each cost descriptor (a) taxonomy in general (b) plant taxonomy (c) vertebrate taxonomy (d) arthropod taxonomy (e) mollusc taxonomy (f) environment (g) protection (h) economic sector (i) type of cost and (j) type of management cost. See methods for description of categories.

aquatic and semi-aquatic environments contributed with $35 \%$ and $5 \%$ of the costs, respectively; the number of entries was much higher for terrestrial environments (Fig. $2 \mathrm{f})$. Only $10 \%$ of the total costs were reported to occur specifically in protected areas 
(a)

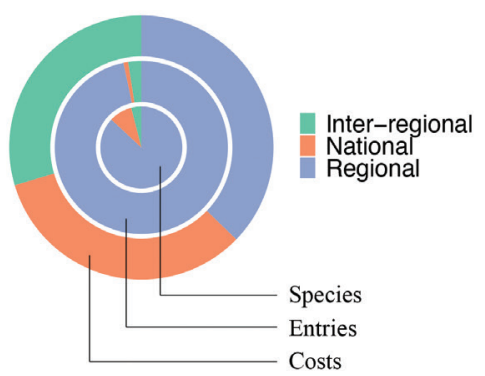

(c)

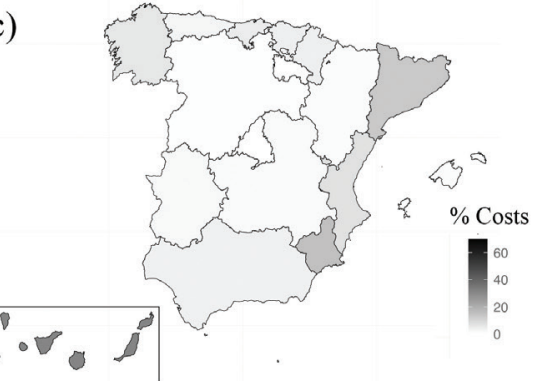

(b)

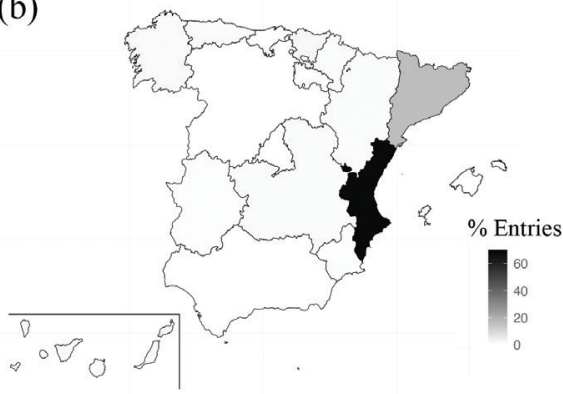

(d)

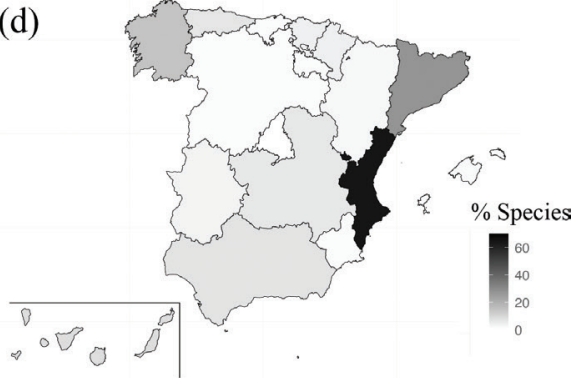

Figure 3. Distribution of the observed economic costs of biological invasions in Spain across the autonomous regions (a) relative importance of country, inter-regional and regional levels in costs and number of species with costs (b) proportion of entries (c) total economic costs (US\$ million), and (d) number of species with costs. All values correspond to the robust data (reported, incurred and reliable costs); values in (b) and (d) correspond to the raw data and (c) to the expanded data.

(Fig. $2 \mathrm{~g}$ ). The most impacted sector was authorities and stakeholders (92\%, Fig. $2 \mathrm{~h}$ ); i.e. governmental services and/or official organisations (e.g. conservation departments) that allocate efforts to the management of IAS (e.g. prevention, eradication campaigns, control or monitoring programmes, research funding). The forestry and health economic sectors had only one (for B. mucronatus) and two (for Ambrosia artemisiifolia) entries, respectively. These entries consisted of extrapolated amounts and, therefore, were not considered as robust data. Costs impacting agriculture came from both scientific papers (three entries that consisted of extrapolated costs and, thus, not included in the robust data) and information obtained directly from managers (four entries for Pomacea spp.). Less than $1 \%$ of the costs corresponded to economic damage while $92 \%$ corresponded to management costs (Fig. 2i). Taking into account only management costs, most costs reporting management actions consisted in post-invasion management $(74 \%)$, while relatively low costs were spent for knowledge/funding (3\%, including education, communication etc.) and pre-invasion management actions (1\%, Fig. $2 \mathrm{j})$.

Although a high number of entries corresponded to information obtained directly from the regional autonomous communities, economic costs were divided almost equally at the country $(33 \%)$, inter-regional $(30 \%$, such as river basins situated across regions) and regional levels (37\%, Fig. 3a). Within the autonomous regions, there were differences in the amount of costs and number of entries amongst them (Fig. 3b, c). 
Both variables showed different patterns; for example, Valencia reported a high number of detailed entries (i.e. including information on time, location, type of management etc.), while their costs were not as high as those reported by other regions, such as Murcia and Canary Islands. In other cases, for example, Catalonia, a high number of entries corresponded to a high amount of costs. Valencia had the highest number of entries, expanding from 2009 to 2019, followed by Catalonia, from 2014 to 2018 (Fig. $3 \mathrm{~b})$. Canary Islands constituted the region with the highest reported costs, followed by Murcia, Catalonia, Valencia and Galicia (Fig. 3c). The rest of the regions accounted for less than US\$ 5 million. Castilla y León and La Rioja showed the lowest costs (i.e. lower than US\$ 1 million). With respect to the number of IAS managed by region, these largely differed amongst regions, ranging from 1 to 111 IAS (Fig. 3d). Mean number of IAS reported to incur costs amongst regions (16.5) was intermediate between the ones managed at the country level (18) and the ones managed at the inter-regional level (8).

The average annual costs of biological invasions in Spain, taking into account only the robust data, was US\$ 10.85 million (€ 9.66 million) over a time period from 1997 to 2020 (Fig. 4). Most of the robust data were reported between 2017 and 2020. Annual costs increased from US\$ 4.22 million per year ( $€ 376$ million) before 2000 to US\$ 14.60 million per year ( $€ 12.99$ million) in the last four years (Fig. 4). Using the robust dataset, trends of costs in Spain showed an initial increase during the first decade of cost reporting (1997-2007) and seemed to stabilise afterwards (Fig. 4). The apparent decrease in reported costs between 2013 and 2016 is most likely an artefact arising from a lack of cost estimates, given the multi-year delay between occurrence and reporting in literature.

Robust data show that economic damage in Spain was only observed for two species (Dreissena polymorpha and Procambarus clarkii), while the rest of the costs corresponded to managing IAS (Fig. 5a). Of the 174 IAS incurring management costs in Spain (robust data), 63 (36\%) were not recorded as invasive for the country (GISD; http://www.issg.org/database) nor included in the current European or national regulations or proposed to be assessed to potentially include them in European regulations (Fig. 5a, Suppl. material 3). The management costs corresponding to these 63 invasive species (US\$ 48.24 million, $€ 42.93$ million) were recorded in the regions of Asturias (1 species), Balearic Islands (1), Canary Islands (4), Cantabria (1), Castilla La Mancha (1), Catalonia (4), Galicia (4), Navarra (2) and Valencia (46). Most of the costs invested in managing IAS that are not included in national or European regulations corresponded to terrestrial and aquatic plants (Fig. 5b, Suppl. material 3).

The 10 IAS presenting the highest economic costs (considering only robust management costs) include five terrestrial plants, one aquatic plant, two terrestrial animals and two aquatic animals (Table 1). Of these, seven species are included in the national regulations (Arundo donax, Carpobrotus sp., Cenchrus setaceus, Cylindropuntia rosea, Eichhornia crassipes, Rhynchophorus ferrugineus and Vespa velutina) and four in the European regulations of IAS (E. crassipes, C. setaceus, C. rosea and V. velutina). Regarding the number of cost entries of IAS in Spain, $50 \%$ of the entries corresponded to 15 


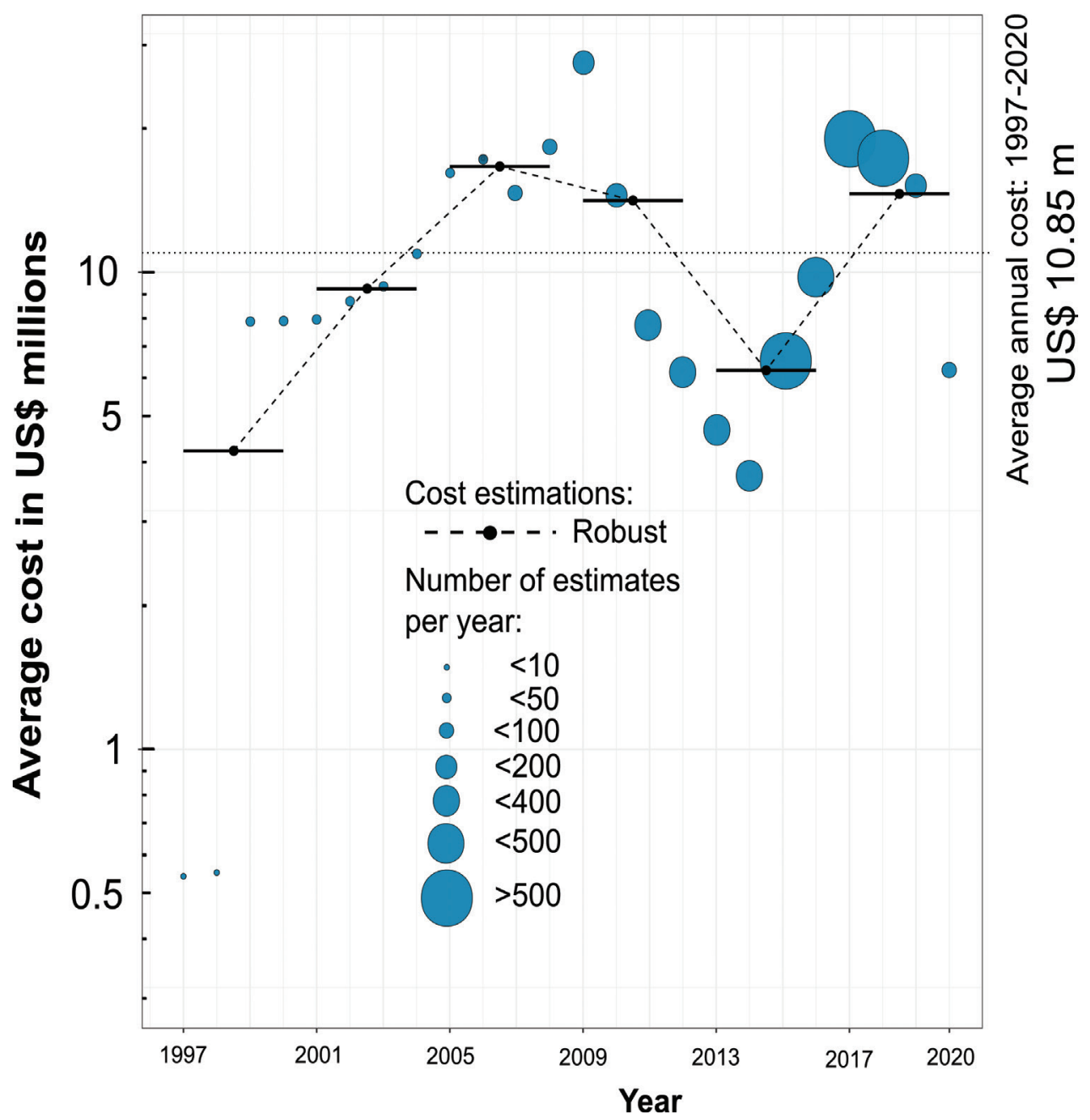

Figure 4. Temporal trends of the economic costs (US\$, log) of invasive alien species in Spain using the robust data (reported, incurred and reliable costs). Each blue circle represents the cumulative cost for a given year, whereas its size is proportional to the number of estimates for that particular year. Average annual costs are calculated in 4-year periods and are represented by black dots and horizontal solid lines. Dashed lines connect the average annual costs for these 4-year periods.

species, all registering more than 50 cost entries each (Suppl. material 4: Fig. S2). The species with the highest number of entries was Cylindropuntia pallida, with a total of 203 records that represent $6.40 \%$ of the data, extracted from a total of six documents from Valencia. The 15 species with the highest number of cost entries did not vary when considering only management costs, while the 15 species with the highest economic costs slightly differed due to the damage reported for D. polymorpha (Suppl. material 4). 
(a)

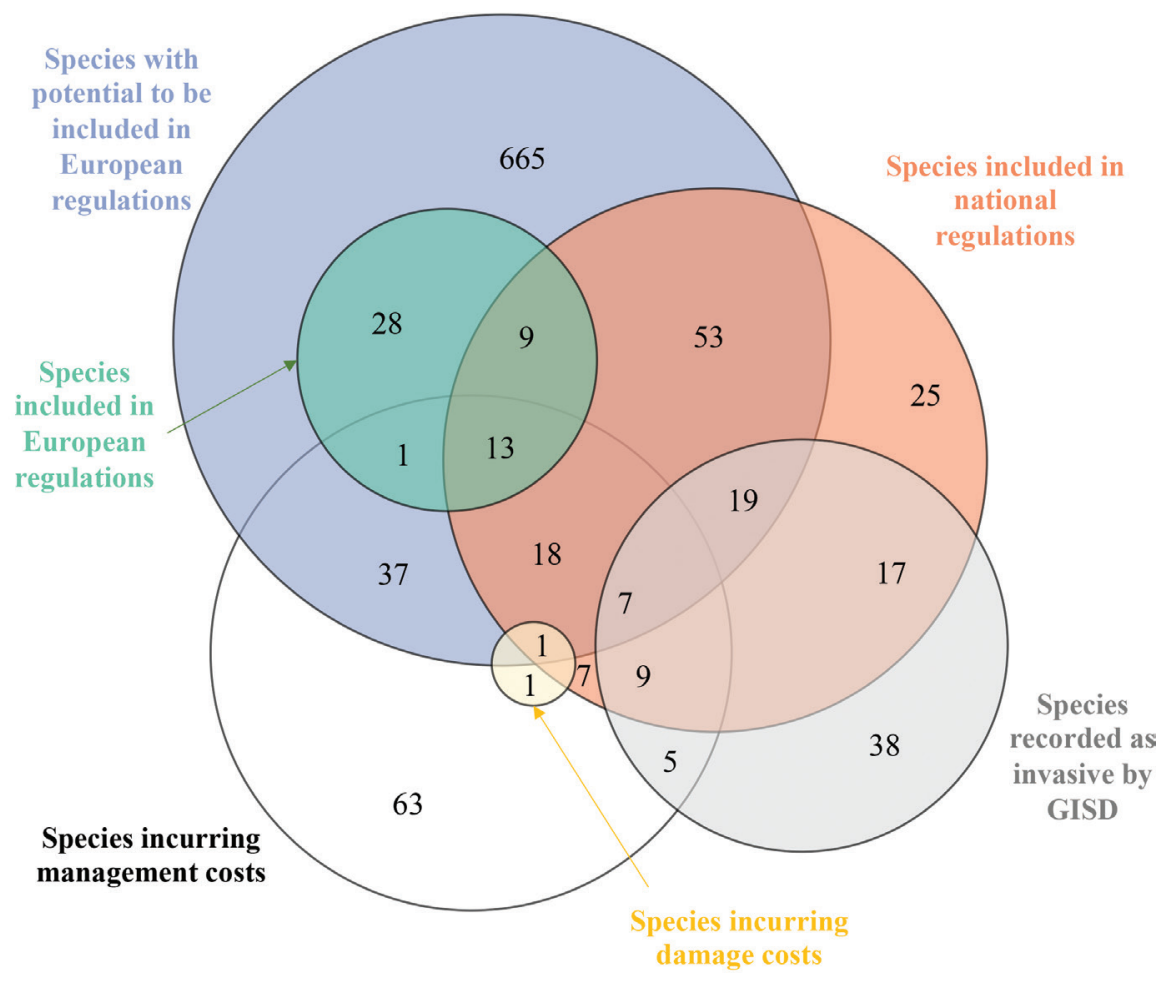

(b)

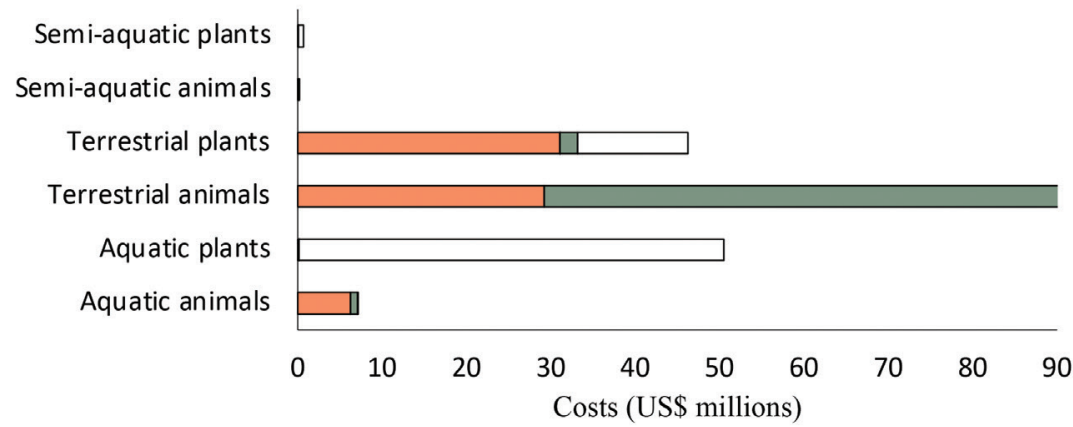

$\square$ Species included in national regulations
$\square$ Species included in European regulations
$\square$ Species included in national and European regulations
$\square$ Species not included in national or European regulations

Figure 5. Invasive species with cost data in Spain with respect to national and international regulations (a) Venn Diagram illustrating the number of invasive species incurring management costs in Spain that are not recorded as invasive in the country (GISD; Pagad et al. 2018), listed in European or national regulations or proposed as potential candidates to be included in European regulations. Numbers indicate the number of invasive species (b) costs (in US\$ millions) incurred by taxonomy and environment of those IAS incurring management costs in Spain, that are included in national regulations, in European regulations or in neither one. 
Table I. Lists of the ten costliest species in Spain considering only robust management costs. Costs are in US\$ million; "Environ" corresponds to the environment where the cost occurred, "Taxon" refers to the taxonomic group of the species; "Regulation" indicates whether the species is listed in national (SP) and/ or European (EU) regulations.

\begin{tabular}{llccc}
\hline \multicolumn{1}{c}{ Species } & Costs & Environ & Taxon & Regulation \\
\hline Eichhornia crassipes & 55.63 & Aquatic & Plant & SP \& EU \\
Eucalyptus sp. & 50.25 & Terrestrial & Plant & - \\
Rhynchophorus ferrugineus & 24.12 & Terrestrial & Animal & SP \\
Arundo donax & 13.98 & Terrestrial & Plant & SP \\
Cenchrus setaceus & 10.13 & Terrestrial & Plant & SP \& EU \\
Neovison vison & 7.91 & Aquatic & Animal & - \\
Pomacea maculata & 6.20 & Aquatic & Animal & - \\
Vespa velutina & 5.33 & Terrestrial & Animal & SP \& EU \\
Carpobrotus sp. & 4.92 & Terrestrial & Plant & SP \\
Cylindropuntia rosea & 2.92 & Terrestrial & Plant & SP \& EU \\
\hline
\end{tabular}

* The taxonomy of $P$. maculata is not clear; however, it was reported with this name in the InvaCost database.

\section{Discussion}

\section{General costs of IAS in Spain}

We analysed economic costs of IAS occurring in Spain and explored more than 3,000 entries, using the InvaCost database and additional sources. Invasive species cost Spain at least US\$261.28 million between 1997 and 2019. Contrary to what Haubrock et al. (2021a) found at the European continent scale, our estimations of expenditure were mostly incurred by governmental organisations (including regional administrations and river basin authorities) in managing IAS ( $92 \%$ of all costs). Damage costs were only found for two species (i.e. D. polymorpha and Procambarus clarkii). Since a large number of invasive species are known to cause high environmental and socioeconomic impacts in Spain (Andreu et al. 2009), these results highlight the need for future investments in research efforts to understand and quantify the economic damage of biological invasions in the country. Such knowledge on the economic damages of IAS in Spain could help increasing societal awareness, prioritising the management of IAS and motivating further investments in IAS management actions.

Compared with other countries of the Mediterranean basin, Spain has been reported as the fifth most impacted country regarding observed costs associated with IAS (Kourantidou et al. 2021), after France (US $\$ 781$ billion, $n=1,036$ cost entries), Italy (US $\$ 503$ million, $\mathrm{n}=94$ ), Libya (US\$340 million, $\mathrm{n}=4$ ) and Turkey (US\$326 million, $\mathrm{n}=11$ ). From a continental perspective, Haubrock et al. (2021a) ranked Spain at a similar place than The Netherlands and Ireland, both countries being much smaller than Spain.

As for other countries and regions, our results show that not accounting for sources of information besides those written in English would have led to a significant knowledge gap and bias for this first assessment of global costs of invasive species in Spain (Angulo et al. 2021). The majority of costs and entries in our dataset came from non-English sources, mainly consisting of unpublished documents in Spanish, which 
resulted in a high percentage of cost entries reported in Spanish (98\%), consistent with findings in some other European countries that reported costs in their native language (e.g. 97\% for France, Renault et al. 2021; 69\% for Germany, Haubrock et al. 2021b). For instance, in Central and South America over 40\% of cost estimates came from Spanish and Portuguese sources (Heringer et al. 2021); and in Ecuador 51.8\% of the costs were reported in Spanish (Ballesteros-Mejia et al. 2021). An extreme situation is observed in Japan, where all recorded costs were in Japanese (Watari et al. 2021), although this was a common trend in Asia (reviewed in Liu et al. 2021).

Management costs focused in aquatic and terrestrial environments, but mostly targeting invasive plants. The costliest invasive species in Spain was the aquatic plant E. crassipes (commonly known as water hyacinth), which was first recorded in the Guadiana River in 2004 and by 2005 it was already covering $75 \mathrm{~km}$ of the river surface. A large research effort has been invested in understanding the management options available to control this invasive plant. For example, in 2008, a workshop, arranged by European organisations, was attended by international experts, aiming to share experiences in the management of E. crassipes (e.g. the successes or failures resulting from applying different management actions) to facilitate the design of management actions in the Guadiana River (http://archives.eppo.int/meeTingS/2008_conferences/ eic-chornia_workshop.htm). However, its management is still a challenge for the area (Téllez et al. 2008; Kriticos and Brunel 2016). This species, together with D. polymorpha or Neovison vison, which are amongst the ten costliest species in Spain, are also amongst the invasive aquatic species causing the most widespread economic impacts (Cuthbert et al. 2021a). E. crassipes also seems to be one of the costliest species in several African countries, in Asia and in North American countries, such as Mexico (Diagne et al. 2021b; Liu et al. 2021; Rico-Sánchez 2021); while D. polymorpha seems to be very costly in the USA and $N$. vison in other European countries such as Germany (Crystal-Ornelas et al. 2021; Haubrock et al. 2021b). Being in the list of the 100 of the worst invasive species, $D$. polymorpha was also ranked as the $8^{\text {th }}$ costliest species of that list (Cuthbert et al. 2021b).

\section{Regional management and the need for effective national coordination of actions}

Regional administrations unequally reported costs, with regions, such as Catalonia or Valencia, reporting detailed annual economic costs from the last decade and others reporting relatively low amounts of costs. Many of the regions reporting high numbers of entries and large amounts of costs present high levels of development, trading and tourism activities, which are normally associated with biological invasions (Pyšek et al. 2010; Haubrock et al. 2021a). However, regional administrations reporting low numbers of entries and low costs are also largely invaded by IAS (e.g. Dana et al. 2009) and, therefore, might need further investments in reporting and managing IAS in the future. 
The use of lists including IAS with known invasive potential is a widely used regulation tool at international and national levels (García-de-Lomas and Vila 2015). Most Spanish regions relied on the national catalogue of IAS rather than establishing their own regional listing (except, for example, Valencia). Based on the national list, managers can prioritise either IAS already present and expanded in their regions or the ones identified as potentially harmful in the future, in order to prevent their entrance. However, our results show that economic costs for pre-invasion management actions related to biosecurity issues, such as early detection, early warning, risk assessment or prioritisation analyses, constituted less than $1 \%$ of all costs; while most economic costs (74\%) were spent in post-invasion management actions, such as monitoring, control or eradication. Although the importance of prevention rather than post-invasion management to efficiently manage IAS is known (Leung et al. 2012; Wilson et al. 2016), there could be an under-estimation of the costs of pre-invasion management actions in the data analysed for Spain. In many cases, managers communicating costs recognised that some prevention actions, such as risk analyses or monitoring for early detection, were not included in the reported costs, as no additional funding was required to implement such actions (e.g. managers use already existing resources, their time, computers or cars), while eradication or control campaigns need extra work (i.e. worker teams, machinery etc.).

A large number of the managed invasive species (63 IAS, 36\% of all managed species) were not listed as invasive in Spain (sensu the GISD database; http://www. issg.org/database), included in European regulations or proposed to be assessed to potentially include them in European regulations. This suggests that Spanish environmental managers do not prioritise the management of invasive species according to current regulations or tools, such as the Global Invasive Species Database, or published expert assessments. The rationale for prioritising the management of IAS in the country, therefore, remains unknown. One possible explanation is that some managers are following the common approach of developing and implementing management actions for groups of species with similar management requirements, instead of doing this separately for individual species (van Wilgen et al. 2011). For example, in 2019, the Global Cactus Working Group (GCWG) identified a set of invasive and potentially-invasive cacti and key actions that can be taken to manage them worldwide (Novoa et al. 2019). In our dataset, six of the cactus species identified as invasive by the GCWG have reported management costs. However, only two of these are included in national regulations. Additionally, our data showed that, in aquatic environments, control of known invasive species, such as invasive turtles, fishes or crayfishes, lead to capture of other nonnative species as a by-catch, such as other turtles of different genera (e.g. Graptemys, Mauremys or Pelodiscus), fishes (e.g. Carassius auratus) or crayfishes (e.g. Callinectes sapidus), not included in national regulations. Managing species that are not included in national lists is not uncommon; for example, Elvira and Almodóvar (2019) showed that only 2 out of 11 fish species introduced in Spain since 2000 
are included in the national catalogue. Even if it is laudable and even encouraging that most managers are proactive and in advance of regulations, we suggest that the national catalogue should be revised to account for all species that are or should be managed.

A substantial amount of research has been recently focused on developing strategies to prioritise the management of IAS, including optimisation frameworks and decision processes (e.g. McGeoch et al. 2016; Curtois et al. 2018; Novoa et al. 2018), all in collaboration with different stakeholder groups (Novoa et al. 2020). Our results suggest that future efforts should focus on stakeholder engagement in Spain, in order to develop transparent and evidence-based management decisions. Moreover, inter-regional management costs, such as those incurred in river basins, were equal to the sum of the costs of all regions together. Such inter-regional management actions are generally more effective than single regional ones, since managing different species pools in neighbouring regions can hinder the effectiveness of the actions at larger geographic scales (Faulkner et al. 2020). Therefore, species prioritisation should ideally be done in collaboration with neighbouring regions in order to achieve effective management results (Sutcliffe et al. 2017).

Our results suggest that there is a need for a country-level organism responsible for the management of IAS that can effectively coordinate joint management strategies, facilitate communication and collaboration between regional governments, national and inter-regional agencies (such as river basin authorities), neighbouring countries and other stakeholders (Caffrey et al. 2014; Piria et al. 2017). This will motivate the continuity of long-lasting management actions and reporting of the costs of IAS that will adequately provide information for future budgets increasing management effectiveness (Pergl et al. 2020). The non-native species secretariat in the UK (http://www. nonnativespecies.org/) is a good reference for this, while a starting point in clarifying competencies across different administrations is suggested.

\section{The good and the bad: high costs in aquatic environments and low costs in protected areas}

Although terrestrial environments had more and higher reported costs than other environments(US\$ 138.6 million), invasions were also relatively costly in aquatic (US\$ 91.9 million) and semi-aquatic environments (US\$ 12.4 million). There are generally few reports on the global economic impacts of invasive species in aquatic ecosystems (Lovell et al. 2006). However, compared with the whole InvaCost database (Diagne et al. 2020b), our estimates for these ecosystems are exceptionally high (but see the case of Mexico, Rico-Sánchez et al. 2021). A global assessment of all data included in InvaCost reported that the monetary costs of aquatic invasive species only constituted $5 \%$ of the total reported costs. This percentage increased to only $9 \%$ when considering management costs only (Cuthbert et al. 2021a). In contrast, we show that, in Spain, 35\% of the funds allocated to the management of invasive species were 
spent in aquatic environments (plus 5\% in semi-aquatic environments). Interestingly, some of the management costs reported by the river basin authorities along the Iberian Peninsula river basins were really high, such those reported in the Guadiana River related to the control of the water hyacinth (E. crassipes) since 2005 or that from the Ebro Basin related to the control of the Zebra mussel (D. polymorpha) in the 2000s (Table 1).

Protected areas in the Iberian Peninsula are known to be effective as natural biodiversity refugia (Araújo, Lobo and Moreno 2007; Gaston et al. 2008). In some Spanish regions, such as Andalusia, protected areas represent $30.5 \%$ of the total surface, which was reported as more than twice the European average (13.7\%, Angulo et al. 2016). However, our results show that only $10.3 \%$ of the economic costs of IAS in the country $(8.2 \%$ of cost entries) incurred specifically in protected areas in Spain. These low numbers suggest a lower reporting of costs or a lower investment in managing IAS in protected areas than in non-protected land, which is worrisome given the high ecological impacts of IAS in protected areas in the country. For example, Gallardo et al. (2017) showed that $38 \%$ of marine and $24 \%$ of inland protected areas in Europe were already affected by at least one of the 86 most threatening invasive species in Europe. Moreover, Capdevilla-Argüelles and Gallardo (2019) ranked a set of top-invaders by their menace to the Spanish national parks and some of those that constituted the highest menace, are amongst the ones we reported here with the highest costs, such as E. crassipes, Cenchrus setaceus, N. vison, V. velutina or Cortaderia selloana. Furthermore, Moodley et al. (2021) classified Baccharis halimifolia and V. velutina among the costliest species in European protected areas, while $N$. vison was among the costliest in semi-aquatic environments within protected areas $\left(B\right.$. halimifolia was ranked $11^{\text {th }}$ in Spain when looking only at management costs). However, it could be that our data are conservative regarding the real costs incurred in protected areas. For example, Saavedra and Medina (2020) showed that an eradication programme implemented in La Palma Island, Spain, prevented the expansion of the ring-necked parakeet (Psittacula krameri) into La Palma Island Biosphere. These costs were, however, recorded at the island level, not only in the protected lands.

\section{Limitations of the study}

Our study shows high economic costs of IAS in Spain, despite our conservative selection of data. Mainly, four potential sources of costs in Spain remained unexplored. On the one hand, while most protected areas are managed by the regional authorities, national parks, the most important figure of conservation for protected areas in Spain, are managed by a national authority, the Autonomous Organism of National Parks (OAPN). Although we also contacted environmental managers from the OAPN, they could not provide us with data on the economic costs of IAS, since this was not readily available. The main reason for this was that their management is shared by a number of private enterprises (mainly from the TRAGSA group) that 
work for the administration in broad public services, not only in the management of invasive species (Pep Amegual, Chief of Research Office in the OAPN, pers. comm.). Therefore, future engagement with these enterprises is needed to include these data in further analysis.

On the other hand, many research projects in Spain, commonly founded by national or international agencies, study biological invasions, despite few entries reporting research costs $(n=166)$. Scalera $(2010)$ reported an increasing number of EU funded projects focusing on IAS from 1992 to 2006, with a budget for this period exceeding $€ 132$ million; Spain, together with Italy and France, hosted 52\% of these projects. Although we approached European Programmes' Advisors from the Spanish National Research Council (CSIC) and searched the web of the Ministry for Education and Professional Career, the information on these costs was difficult to obtain. We only consider costs of a few European projects that took place in Spain, for which cost information was available on the web or was reported by targeted researchers (i.e. Invasep, Ripisilva, Lampropeltis, ConHabit, Margal Ulla, La Rioja Life, Estuarios del Pais Vasco). New ways to obtain this information are needed in order to include such economic costs in future assessments.

Third, even if costs for invasive aquatic species were well reported in our database, costs for marine species were not reported in Spain; a possible explanation is that we did not specifically target national administrations with governance in marine species. However, this is a common problem for the global InvaCost project, since only $2 \%$ of all global aquatic invasion costs were related to marine-tolerant invasive species (Cuthbert et al. 2021a).

Finally, border controls, phytosanitary measures against invasive pests or private efforts to control invaders, have not been searched specifically. Border control measures exist in Spain. For example, in the Canary Islands, there are strict border controls, but control of invasive species is difficult to quantify separately from other border activities. Some private efforts have been recorded, such as those targeting the eradication of the first outbreak of the invasive termite Reticulitermes flavipes in Tenerife Island between 2010 and 2015 (Hernández-Teixidor et al. 2019) or the management of $D$. polymorpha in the Ebro Basin, which costs $€ 615,000 /$ year to energy companies and $€ 321,450$ in 2009 to the private companies using its water (Durán et al. 2012). However, we argue for a better reporting of these private costs. In relation to damage caused by invaders, it is likely that our targeted research did not succeed in obtaining such information from the public administrations that could hold such data. For example, our database does not include data on damage caused to agriculture or forestry by invasive pest species, such as apple snails or bark beetles (Golzanadera et al. 2012; Joshi and Parera 2017) or damage caused by disease vectors, such as health-associated costs by invasive Aedes sp. mosquitoes (Collantes et al. 2015). However, it could also depend on how local funds are distributed, prioritising management actions rather than damage evaluation, which would require additional resources and scientific skills. 


\section{Conclusion}

This study is the first one attempting to economically evaluate the impact of IAS in Spain. We collected cost data mainly from the literature, regional governments and river basin authorities. Beside certain extrapolated costs on the economic impacts of IAS in the forestry sector, most of the reported costs consisted of funding used for managing established IAS (such as control or monitoring costs). Despite invasive species posing high environmental and economic impacts in Spain (Andreu et al. 2009), most of the collected costs corresponded to management actions, while damage costs were only found for two species. These results suggest the need for further investment in understanding the damage costs of IAS in the country and reporting them. Taxonomically, Spanish environmental managers expended more funds in managing invasive plants than animals and substantial efforts were directed to manage IAS in aquatic environments. From a geographic perspective, a country-level organism responsible for the management of IAS could promote long-lasting research-based management strategies and reporting of costs that expand political borders amongst regions and efficiently coordinate actions amongst all the implicated actors.

\section{Acknowledgements}

We want to acknowledge all environmental managers, national officials, practitioners and researchers who kindly answered our request for information about the costs of invasive species. We are particularly indebted to Phillip J. Haubrock for his unfailing dedication to help with $\mathrm{R}$, as well as his unwavering commitment at any time. We also want to thank Paride Balzani, Ahmed Taheri, Gustavo Heringer, Juli Broggi and Maider Iglesias-Carrasco for the translation of the abstract in Italian, Arabic, Portuguese, Catalan and Basque respectively. Finally, we would like to thank all the InvaCost's secret agents that helped us to refine data and remove duplicates and overlaps during the review process, led by the eagle eyes of Nigel G. Taylor. The French National Research Agency (ANR-14-CE02-0021) and the BNP-Paribas Foundation Climate Initiative funded the InvaCost project that allowed the construction of the InvaCost database. The present work was conducted following a workshop funded by the AXA Research Fund Chair of Invasion Biology and is part of the AlienScenario project funded by BiodivERsA and Belmont-Forum Call 2018 on biodiversity scenarios. Funds for EA and LBM contracts came from the AXA Research Fund Chair of Invasion Biology of University Paris Saclay. CD was funded by the BiodivERsA-Belmont Forum Project "Alien Scenarios" (BMBF/ PT DLR 01LC1807C). AN acknowledges funding from EXPRO grant no. 1928807X (Czech Science Foundation) and long-term research development project RVO 67985939 (Czech Academy of Sciences). 


\section{References}

Andreu J, Vilà M, Hulme PE (2009) An assessment of stakeholder perceptions and management of noxious alien plants in Spain. Environmental Management 43(6): e1244. https:// doi.org/10.1007/s00267-009-9280-1

Angulo E, Boulay R, Ruano F, Tinaut A, Cerdá X (2016) Anthropogenic impacts in protected areas: assessing the efficiency of conservation efforts using Mediterranean ant communities. PeerJ 4: e2773. https://doi.org/10.7717/peerj.2773

Angulo E, Diagne C, Ballesteros-Mejia L, Ahmed DA, Banerjee AK, Capinha C, Courchamp F, Renault D, Roiz D, Dobigny G, Haubrock P, Heringer G, Verbrugge LNH, Golivets M, Nuñez MA, Kirichenko N, Dia CAKM, Xiong W, Adamjy T, Akulov E, Duboscq-Carra V, Kourantidou M, Liu C, Taheri A, Watari Y (2020) Non-English database version of InvaCost. https://doi.org/10.6084/m9.figshare.12928136.v1

Angulo E, Diagne C, Ballesteros-Mejia L, Adamjy T, Ahmed DA, Akulov E, Banerjee AK, Capinha C, Dia CAKM, Dobigny G, Duboscq-Carra VG, Golivets M, Haubrock PJ, Heringer G, Kirichenko N, Kourantidou M, Liu C, Nuñez MA, Renault D, Roiz D, Taheri A, Verbrugge L, Watari Y, Xiong W, Courchamp F (2021) Non-English languages enrich scientific knowledge: the example of economic costs of biological invasions. Science of the Total Environment 775: e144441. https://doi.org/10.1016/j.scitotenv.2020.144441

Araújo MB, Lobo JM, Moreno JC (2007) The effectiveness of Iberian protected areas in conserving terrestrial biodiversity. Conservation Biology 21: 1423-1432. https://doi. org/10.1111/j.1523-1739.2007.00827.x

Aukema JE, Leung B, Kovacs K, Chivers C, Britton KO, Englin J, Frankel SJ, Haight RG, Holmes TP, Liebhold AM, McCullough DG, Von Holle B (2011) Economic impacts of nonnative forest insects in the continental United States. PLoS ONE 6(9): e24587. https://doi. org/10.1371/journal.pone.0024587

Ballesteros-Mejia L, Angulo E, Diagne C, Cooke B, Nuñez MA, Courchamp F (2021) Economic costs of biological invasions in Ecuador: the importance of the Galapagos Islands. In: Zenni RD, McDermott S, García-Berthou E, Essl F (Eds) The economic costs of biological invasions around the world. NeoBiota 67: 375-400. https://doi.org/10.3897/neobiota.67.59116

Bellard C, Cassey P, Blackburn T (2016) Alien species as a driver of recent extinctions. Biology Letters 12(2): e20150623. https://doi.org/10.1098/rsbl.2015.0623

Blackburn T, Bellard C, Ricciardi T (2019) Alien versus native species as drivers of recent extinctions. Frontiers in Ecology and Environment 17(4): 203-207. https://doi.org/10.1002/ fee. 2020

Bradshaw CJA, Leroy B, Bellard C, Roiz D, Albert C, Fournier A, Barbet-Massin M, Salles J-M, Simard F, Courchamp F (2016) Massive yet grossly underestimated global costs of invasive insects. Nature Communications 7: e12986. https://doi.org/10.1038/ncomms12986

Caffrey JM, Baars JR, Barbour JH, Boets P, Boon P, Davenport K, Dick JT, Early J, Edsman L, Gallagher C, Gross J, Heinimaa P, Horrill C, Hudin S, Hulme PE, Hynes S, MacIsaac HJ, McLoone P, Millane M, Moen TL, Moore N, Newman J, O’Conchuir R, O'Farrell M, O’Flynn C, Oidtmann B, Renals T, Ricciardi A, Roy H, Shaw R, Weyl O, Williams F, Lucy FE (2014) Tackling invasive alien species in Europe: the top 20 issues. Management of Biological Invasions 5(1): 1-20. https://doi.org/10.3391/mbi.2014.5.1.01 
Capdevila-Argüelles L, Gallardo B (2019) El proyecto BIOCAMBIO: Invasiones biológicas en la red de parques nacionales. Cátedra Parques Nacionales. Universidad de Alcalá, Servicio de Publicaciones, España. Monografías Ciencias 6, 227 pp. [ISBN: 978-84-17729-30-1]

Carboneras C, Genovesi P, Vilà M, Blackburn TM, Carrete M, Clavero M, D’hondt B, Orueta JF, Gallardo B, Geraldes P, González-Moreno P (2018) A prioritised list of invasive alien species to assist the effective implementation of EU legislation. Journal of Applied Ecology 55(2): 539-547. https://doi.org/10.1111/1365-2664.12997

Collantes F, Delacour S, Alarcón-Elbal PM, Ruiz-Arrondo I, Delgado JA, Torrell-Sorio A, Bengoa M, Eritja R, Miranda MÁ, Molina R, Lucientes J (2015) Review of ten-years presence of Aedes albopictu s in Spain 2004-2014: known distribution and public health concerns. Parasites \& Vectors 8(1): 1-1. https://doi.org/10.1186/s13071-015-1262-y

Crystal-Ornelas R, Hudgins EJ, Cuthbert RN, Haubrock PJ, Fantle-Lepczyk J, Angulo E, Kramer AM, Ballesteros-Mejia L, Leroy B, Leung B, López-López E, Diagne C, Courchamp F (2021) Economic costs of biological invasions within North America. In: Zenni RD, McDermott S, García-Berthou E, Essl F (Eds) The economic costs of biological invasions around the world. NeoBiota 67: 485-510. https://doi.org/10.3897/neobiota.67.58038

Cuthbert RN, Bacher S, Blackburn TM, Briski E, Diagne C, Dick JTA, Essl F, Genovesi P, Haubrock PJ, Latombe G, Lenzner B, Meinard Y, Pauchard A, Pyšek P, Ricciardi A, Richardson DM, Russell JC, Simberloff D, Courchamp F (2020) Invasion costs, impacts, and human agency: response to Sagoff. Conservation Biology 34: 1579-1582. https://doi. org/10.1111/cobi.13592

Cuthbert RN, Diagne C, Haubrock PJ, Turbelin AJ, Courchamp F (2021b) Are the "100 of the world's worst" invasive species also the costliest? Biological Invasions (2021). https:// doi.org/10.21203/rs.3.rs-227453/v1

Cuthbert RN, Pattison Z, Taylor NG, Verbrugge L, Diagne C, Ahmed DA, Leroy B, Angulo E, Briski E, Capinha C, Catford JA, Dalu T, Essl F, Gozlan RE, Haubrock PJ, Kourantidou M, Kramer AM, Renault D, Wasserman RJ, Courchamp F (2021a) Global economic costs of aquatic invasive alien species. Science of the Total Environment 775: e145238. https:// doi.org/10.1016/j.scitotenv.2021.145238

Courtois P, Figuieres C, Mulier C, Weill J (2018) A cost-benefit approach for prioritizing invasive species. Ecological Economics 146: 607-620. https://doi.org/10.1016/j. ecolecon.2017.11.037

Dana ED, García-de-Lomas J, Garrido JR, Gonzalez-Miras E, Ceballos G, Ortega F (2009) Management of invasive alien species in Andalusia (Southern Spain): some successful experiences. Aliens 28: 50-51.

Dawson W, Moser D, Van Kleunen M, Kreft H, Pergl J, Pyšek P, Weigelt P, Winter M, Lenzner B, Blackburn TM, Dyer EE, Cassey P, Scrivens SL, Economo EP, Guénard B, Capinha C, Seebens H, García-Díaz P, Nentwig W, García-Berthou E, Casal C, Mandrak NE, Fuller P, Meyer C, Essl F (2017) Global hotspots and correlates of alien species richness across taxonomic groups. Nature Ecology \& Evolution 1: 1-7. https://doi.org/10.1038/s41559017-0186

Durán C, Lanao M, Pérez y Pérez L, Chica C, Anadón A, Touya V (2012) Estimación de los costes de la invasión del mejillón cebra en la cuenca del Ebro (periodo 2005-2009). Limnetica 31(2): 213-230. 
Diagne C, Catford JA, Essl F, Nuñez MA, Courchamp F (2020a) What are the economic costs of biological invasions? A complex topic requiring international and interdisciplinary expertise. NeoBiota 63: 25-37. https://doi.org/10.3897/neobiota.63.55260

Diagne C, Leroy B, Gozlan R, Vaissière A-C, Assailly C, Nuninger L, Roiz D, Jourdain F, Jarić I, Courchamp F (2020b) InvaCost, a public database of the economic costs of biological invasions worldwide. Scientific Data 7: 1-12. https://doi.org/10.1038/s41597-020-00586-z

Diagne C, Leroy B, Vaissière A-C, Gozlan RE, Roiz D, Jarić I, Salles JM, Bradshaw CJA, Courchamp F (2021a) High and rising economic costs of biological invasions worldwide. Nature 592: 571-576. https://doi.org/10.1038/s41586-021-03405-6

Diagne C, Turbelin AJ, Moodley D, Novoa A, Leroy B, Angulo E, Adamjy T, Dia CAKM, Taheri A, Tambo J, Dobigny G, Courchamp F (2021) The economic costs of biological invasions in Africa: a growing but neglected threat? In: Zenni RD, McDermott S, GarcíaBerthou E, Essl F (Eds) The economic costs of biological invasions around the world. NeoBiota 67: 11-51. https://doi.org/10.3897/neobiota.67.59132

Ehrenfeld JG (2011) Ecosystem consequences of biological invasions. Annual Review of Ecology, Evolution, and Systematics 41: 59-80. https://doi.org/10.1146/annurev-ecolsys-102209-144650

Elvira B, Almodóvar A (2019) El problema de los peces de agua dulce invasores en España. Especies exóticas invasoras. Cátedra Parques Nacionales. Universidad de Alcalá, Servicio de Publicaciones, España. Monografías Ciencias 6, 227 pp. [ISBN: 978-84-17729-30-1]

Faulkner KT, Robertson MP, Wilson JR (2020) Stronger regional biosecurity is essential to prevent hundreds of harmful biological invasions. Global Change Biology 26(4): 2449-2462. https://doi.org/10.1111/gcb.15006

García-de-Lomas J, Vilà M (2015) Lists of harmful alien organisms: Are the national regulations adapted to the global world? Biological Invasions 17(11): 3081-3091. https://doi. org/10.1007/s10530-015-0939-7

Gallardo B, Aldridge DC, González-Moreno P, Pergl J, Pizarro M, Pyšek P, Thuiller W, Yesson C, Vilà M (2017) Protected areas offer refuge from invasive species spreading under climate change. Global Change Biology 23(12): 5331-5343. https://doi.org/10.1111/gcb.13798

Gaston KJ, Jackson SF, Cantú-Salazar L, Cruz-Piñón G (2008) The ecological performance of protected areas. Annual Review of Ecology and Systematics 39: 93-113. https://doi. org/10.1146/annurev.ecolsys.39.110707.173529

Goldazarena A, Romón P, López S (2012) Bark beetles control in forests of Northern Spain. In: Soloneski S (Ed.) Integrated pest management and pest control-current and future tactics. IntechOpen, 323-352. [ISBN: 978-953-51-0050-8] https://doi.org/10.5772/30162

Haubrock PJ, Cuthbert RN, Sundermann A, Diagne C, Golivets M, Courchamp F (2021) Economic costs of invasive species in Germany. In: Zenni RD, McDermott S, GarcíaBerthou E, Essl F (Eds) The economic costs of biological invasions around the world. NeoBiota 67: 225-246. https://doi.org/10.3897/neobiota.67.59502

Haubrock PJ, Turbelin AJ, Cuthbert RN, Novoa A, Taylor NG, Angulo E, Ballesteros-Mejia L, Bodey TW, Capinha C, Diagne C, Essl F, Golivets M, Kirichenko N, Kourantidou M, Leroy B, Renault D, Verbrugge L, Courchamp F (2020) Economic costs of invasive alien species across Europe In: Zenni RD, McDermott S, García-Berthou E, Essl F (Eds) The 
economic costs of biological invasions around the world. NeoBiota 67: 153-190. https:// doi.org/10.3897/neobiota.67.58196

Heringer G, Angulo E, Ballesteros-Mejia L, Capinha C, Courchamp F, Diagne C, DuboscqCarra VG, Nuñez MA, Zenni RD (2021) The economic costs of biological invasions in Central and South America: a first regional assessment. In: Zenni RD, McDermott S, García-Berthou E, Essl F (Eds) The economic costs of biological invasions around the world. NeoBiota 67: 401-426. https://doi.org/10.3897/neobiota.67.59193

Hernández-Teixidor D, Suárez D, García J, Mora D (2019) First report of the invasive Reticulitermes flavipes (Kollar, 1837) (Blattodea, Rhinotermitidae) in the Canary Islands. Journal of Applied Entomology 143(4): 478-482. https://doi.org/10.1111/jen.12592

Hulme PE (2006) Beyond control: wider implications for the management of biological invasions. Journal of Applied Ecology 43: 835-847.https://doi.org/10.1111/j.1365-2664.2006.01227.x Jeschke JM, Bacher S, Blackburn TM, Dick JT, Essl F, Evans T, Gaertner M, Hulme PE, Kühn I, Mrugała A, Pergl J (2014) Defining the impact of non-native species. Conservation Biology 28(5): 1188-1119. https://doi.org/10.1111/cobi.12299

Joshi RC, Parera XV (2012) The rice apple snail in Spain: a review. International Pest Control 59(2): 106-108.

Kettunen M, Genovesi P, Gollasch S, Pagad S, Starfinger U, ten Brink P, Shine C (2009) Technical support to EU strategy on invasive alien species (IAS). Institute for European Environmental Policy (IEEP), Brussels, 124 pp.

Kourantidou M, Cuthbert RN, Haubrock PJ, Novoa A, Taylor NG, Leroy B, Capinha C, Renault D, Angulo E, Diagne C, Courchamp F (2021) Economic costs of invasive alien species in the Mediterranean basin. In: Zenni RD, McDermott S, García-Berthou E, Essl F (Eds) The economic costs of biological invasions around the world. NeoBiota 67: 427-458. https://doi.org/10.3897/neobiota.67.58926

Kriticos DJ, Brunel S (2016) Assessing and managing the current and future pest risk from water hyacinth (Eichhornia crassipes), an invasive aquatic plant threatening the environment and water security. PLoS ONE 11(8): e0120054. https://doi.org/10.1371/journal.pone.0120054

Leroy B, Kramer AM, Vaissière A-C, Courchamp F, Diagne C (2020) Analysing global economic costs of invasive alien species with the invacost $\mathrm{R}$ package. BioRXiv. https://doi. org/10.1101/2020.12.10.419432

Leung B, Roura-Pascual N, Bacher S, Heikkilä J, Brotons L, Burgman MA, Dehnen-Schmutz K, Essl F, Hulme PE, Richardson DM, Sol D, Vilà M (2012) TEASIng apart alien species risk assessments: A framework for best practices. Ecology Letters 15(12): 1475-1493. https://doi.org/10.1111/ele.12003

Liu C, Diagne C, Angulo E, Banerjee A-K, Chen Y, Cuthbert RN, Haubrock PJ, Kirichenko N, Pattison Z, Watari Y, Xiong W, Courchamp F (2021) Economic costs of biological invasions in Asia. In: Zenni RD, McDermott S, García-Berthou E, Essl F (Eds) The economic costs of biological invasions around the world. NeoBiota 67: 53-78. https://doi. org/10.3897/neobiota.67.58147

Lovell SJ, Stone SF, Fernandez L (2006) The economic impacts of aquatic invasive species: a review of the literature. Agricultural and Resource Economics Review 35: 195-208. https:// doi.org/10.1017/S1068280500010157 
McGeoch MA, Genovesi P, Bellingham PJ, Costello MJ, McGrannachan C, Sheppard A (2016) Prioritizing species, pathways, and sites to achieve conservation targets for biological invasion. Biological Invasions 18(2): 299-314. https://doi.org/10.1007/s10530-015-1013-1

Moodley D, Angulo E, Cuthbert RN, Leung B, Tubelin A, Novoa A, Kourantidou M, Heringer G, Haubrock PJ, Renault D, Robuchon M, Fantle-Lepczyk J, Courchamp F, Diagne C (2021) Economic costs of biological invasions in protected areas worldwide - where do we stand? Biological Invasion, in review. https://doi.org/10.21203/rs.3.rs-289130/v1

Novoa A, Richardson DM, Pyšek P, Meyerson LA, Bacher S, Canavan S, Catford J, Čuda J, Essl F, Foxcroft LC, Genovesi P, Hirsch H, Hui C, Jackson MC, Kueffer C, Le Roux JJ, Measey J, Mohanty NP, Moodley D, Müller-Schärer H, Packer JG, Pergl J, Robinson TB, Saul W-C, Shackleton RT, Visser V, Weyl OLF, Yannelli FA, Wilson JRU (2020) Invasion syndromes: a systematic approach for predicting biological invasions and facilitating effective management. Biological Invasions 2: 1-20. https://doi.org/10.1007/s10530-02002220-w

Novoa A, Shackleton R, Canavan S, Cybele C, Davies SJ, Dehnen-Schmutz K, Fried J, Gaertner M, Geerts S, Griffiths CL, Kaplan H (2018) A framework for engaging stakeholders on the management of alien species. Journal of Environmental Management 205: 286-297. https://doi.org/10.1016/j.jenvman.2017.09.059

Novoa A, Brundu G, Day MD, Deltoro V, Essl F, Foxcroft LC, Fried G, Kaplan H, Kumschick S, Lloyd S, Marchante E, Marchante H, Paterson ID, Pyšek P, Richardson DM, Witt A, Zimmermann HG, Wilson JRU (2019) Global actions for managing Cactus invasions. Plants 8(10): e421. https://doi.org/10.3390/plants8100421

Pagad S, Genovesi P, Carnevali L, Schigel D, McGeoch MA (2018) Introducing the Global Register of Introduced and Invasive Species. Scientific Data 5: e170202. https://doi. org/10.1038/sdata.2017.202

Pergl J, Pyšek P, Essl F, Jeschke JM, Courchamp F, Geist J, Hejda M, Kowarik I, Mill A, Musseau C, Pipek P, Saul W-C, von Schmalensee M, Strayer D (2020) Need for routine tracking of biological invasions. Conservation Biology 34(5): 1311-1314. https://doi. org/10.1111/cobi.13445

Pimentel D, Zuniga R, Morrison D (2005) Update on the environmental and economic costs associated with alien-invasive species in the United States. Ecological Economics 52: 273288. https://doi.org/10.1016/j.ecolecon.2004.10.002

Piria M, Copp GH, Dick JT, Duplić A, Groom Q, Jelić D, Lucy FE, Roy HE, Sarat E, Simonović P, Tomljanović T (2017) Tackling invasive alien species in Europe II: threats and opportunities until 2020. Management of Biological Invasions 3: 273-286. https:// doi.org/10.3391/mbi.2017.8.3.02

Pyšek P, Jarošík V, Hulme PE, Kühn I, Wild J, Arianoutsou M, Bacher S, Chiron F, Didžiulis V, Essl F, Genovesi P (2010) Disentangling the role of environmental and human pressures on biological invasions across Europe. Proceedings of the National Academy of Sciences 107(27): 12157-12162. https://doi.org/10.1073/pnas.1002314107

Renault D, Manfrini E, Leroy B, Diagne C, Ballesteros-Mejia L, Angulo E, Courchamp F (2021) Biological invasions in France: Alarming costs and even more alarming knowledge 
gaps. In: Zenni RD, McDermott S, García-Berthou E, Essl F (Eds) The economic costs of biological invasions around the world. NeoBiota 67: 191-224. https://doi.org/10.3897/ neobiota.67.59134

Rico-Sánchez AE, Haubrock PJ, Cuthbert RN, Angulo E, Ballesteros-Mejia L, López-López E, Duboscq-Carra VG, Nuñez MA, Diagne C, Courchamp F (2021) Economic costs of invasive alien species in Mexico. In: Zenni RD, McDermott S, García-Berthou E, Essl F (Eds) The economic costs of biological invasions around the world. NeoBiota 67: 459483. https://doi.org/10.3897/neobiota.67.63846

Saavedra S, Medina FM (2020) Control of invasive ring-necked parakeet (Psittacula krameri) in an island Biosphere Reserve (La Palma, Canary Islands): combining methods and social engagement. Biological Invasions 22(12): 3653-3667. https://doi.org/10.1007/s10530020-02351-0

Scalera R (2010) How much is Europe spending on invasive alien species? Biological Invasions 12(1): 173-177. https://doi.org/10.1007/s10530-009-9440-5

Seebens H, Gastner MT, Blasius, B, Courchamp F (2013) The risk of marine bioinvasion caused by global shipping. Ecology Letters 16(6): 782-790. https://doi.org/10.1111/ele.12111

Simberloff D, Martin J-L, Genovesi P, Maris V, Wardle DA, Aronson J, Courchamp F, Galil B, Garcı-Berthou E, Pascal M, Pysek P, Sousa R, Tabacchi E, Vilà M (2013) Impacts of biological invasions - what's what and the way forward. Trends in Ecology \& Evolution 28(1): 58-66. https://doi.org/10.1016/j.tree.2012.07.013

Sutcliffe C, Quinn CH, Shannon C, Glover A, Dunn AM (2018) Exploring the attitudes to and uptake of biosecurity practices for invasive non-native species: views amongst stakeholder organisations working in UK natural environments. Biological Invasions 20(2): 399-411. https://doi.org/10.1007/s10530-017-1541-y

Téllez TR, López EM, Granado GL, Pérez EA, López RM, Guzmán JM (2008) The water hyacinth, Eichhornia crassipes: an invasive plant in the Guadiana River Basin (Spain). Aquatic Invasions 3: 42-53. https://doi.org/10.3391/ai.2008.3.1.8

Turbelin AJ, Malamud BD, Francis RA (2017) Mapping the global state of invasive alien species: patterns of invasion and policy responses. Global Ecology and Biogeography 26(1): 78-92. https://doi.org/10.1111/geb.12517

van Wilgen BW, Dyer C, Hoffmann JH, Ivey P, Le Maitre DC, Moore JL, Richardson DM, Rouget M, Wannenburgh A, Wilson JRU (2011) National-scale strategic approaches for managing introduced plants: Insights from Australian acacias in South Africa. Diversity and Distributions 17: 1060-1075. https://doi.org/10.1111/j.14724642.2011.00785.x

Watari Y, Komine H, Angulo E, Diagne C, Ballesteros-Mejia L, Courchamp F (2021) First synthesis of the economic costs of biological invasions in Japan. In: Zenni RD, McDermott S, García-Berthou E, Essl F (Eds) The economic costs of biological invasions around the world. NeoBiota 67: 79-101. https://doi.org/10.3897/neobiota.67.59186

Wilson JR, Panetta FD, Lindgren C (2016) Detecting and responding to alien plant incursions. Cambridge University Press, [xviii +] 265 pp. https://doi.org/10.1017/ CBO9781316155318 


\section{Supplementary material I}

\section{Dataset of the economic costs of invasive alien species in Spain and descriptive variables}

Authors: Elena Angulo, Liliana Ballesteros-Mejia, Ana Novoa, Virginia G. DuboscqCarra, Christophe Diagne, Franck Courchamp

Data type: excel file

Explanation note: Spreadsheets: "InvaCost_3.0_Spain" contains the 3,260 raw entries; "InfoVariables" contains information on each variable and their categories; "Corrections": report of corrections made with respect to the original source (Invacost_3.0).

Copyright notice: This dataset is made available under the Open Database License (http://opendatacommons.org/licenses/odbl/1.0/). The Open Database License $(\mathrm{ODbL})$ is a license agreement intended to allow users to freely share, modify, and use this Dataset while maintaining this same freedom for others, provided that the original source and author(s) are credited.

Link: https://doi.org/10.3897/neobiota.67.59181.suppl1

\section{Supplementary material 2}

\section{Figure S1}

Authors: Elena Angulo, Liliana Ballesteros-Mejia, Ana Novoa, Virginia G. DuboscqCarra, Christophe Diagne, Franck Courchamp

Data type: pdf file

Explanation note: (a) Descriptors of the economic costs of invasive alien species in Spain using the non-robust data (extrapolated cost, not occurring and/or unreliable costs) and (b) temporal trends of these economic costs (US\$). In (b), each blue circle represents the cumulative cost for a given year, whereas its size is proportional to the number of estimates for that particular year. Average annual costs are calculated in 4-year periods and are represented by black points and horizontal solid lines. Dashed lines connect the average annual costs for these 4-year periods. Non-robust data started with low values in the 2000s increasing highly (mainly due to the predicted costs for the pine wood nematode) for the period between 2008 and 2030. See sample size in Fig. 1.

Copyright notice: This dataset is made available under the Open Database License (http://opendatacommons.org/licenses/odbl/1.0/). The Open Database License $(\mathrm{ODbL})$ is a license agreement intended to allow users to freely share, modify, and use this Dataset while maintaining this same freedom for others, provided that the original source and author(s) are credited.

Link: https://doi.org/10.3897/neobiota.67.59181.suppl2 


\section{Supplementary material 3}

\section{Lists of species used in Figure 5}

Authors: Elena Angulo, Liliana Ballesteros-Mejia, Ana Novoa, Virginia G. DuboscqCarra, Christophe Diagne, Franck Courchamp

Data type: excel file

Explanation note: Spreadsheets: "Management and damage" contains species recorded as invasive in the country (GISD; Pagad et al. 2018); species in national regulations, European regulations or proposed as potential candidates to be included in European regulations (Carboneras et al. 2018); species having management costs and damage costs in InvaCost. "Management" contains only managed species with their presence in the lists reported in the previous spreadsheet and information about their environment and taxonomy (Env/Phyl), as well as their costs in US\$. "Management_non_listed" contains the species not listed in any of the previous lists and the regions where each one has been reported as having management costs. Codes 1-0 mean presence or absence in the list, respectively.

Copyright notice: This dataset is made available under the Open Database License (http://opendatacommons.org/licenses/odbl/1.0/). The Open Database License $(\mathrm{ODbL})$ is a license agreement intended to allow users to freely share, modify, and use this Dataset while maintaining this same freedom for others, provided that the original source and author(s) are credited.

Link: https://doi.org/10.3897/neobiota.67.59181.suppl3

\section{Supplementary material 4}

\section{Figure S2}

Authors: Elena Angulo, Liliana Ballesteros-Mejia, Ana Novoa, Virginia G. DuboscqCarra, Christophe Diagne, Franck Courchamp

Data type: PDF file

Explanation note: Lists of the costliest species in Spain considering all the cost types or only management costs and separating robust and non-robust data. (A) Economic costs (US\$ million) and (B) number of entries. Colours in the tenth costliest invasive species using the robust data facilitate comparison of species amongst different lists.

Copyright notice: This dataset is made available under the Open Database License (http://opendatacommons.org/licenses/odbl/1.0/). The Open Database License $(\mathrm{ODbL})$ is a license agreement intended to allow users to freely share, modify, and use this Dataset while maintaining this same freedom for others, provided that the original source and author(s) are credited.

Link: https://doi.org/10.3897/neobiota.67.59181.suppl4 